OAK RIDGE

ORNLTM-2001/113

NATIONAL LABORATORY

MANAGED BY UT-BATTELLE

FOR THE DEPARTMENT OF ENERGY

\title{
ASSESSMENT OF NONNATIVE INVASIVE PLANTS IN THE DOE OAK RIDGE NATIONAL ENVIRONMENTAL RESEARCH PARK
}

S. J. Drake, J. F. Weltzin, and P. D. Parr

Environmental Sciences Division
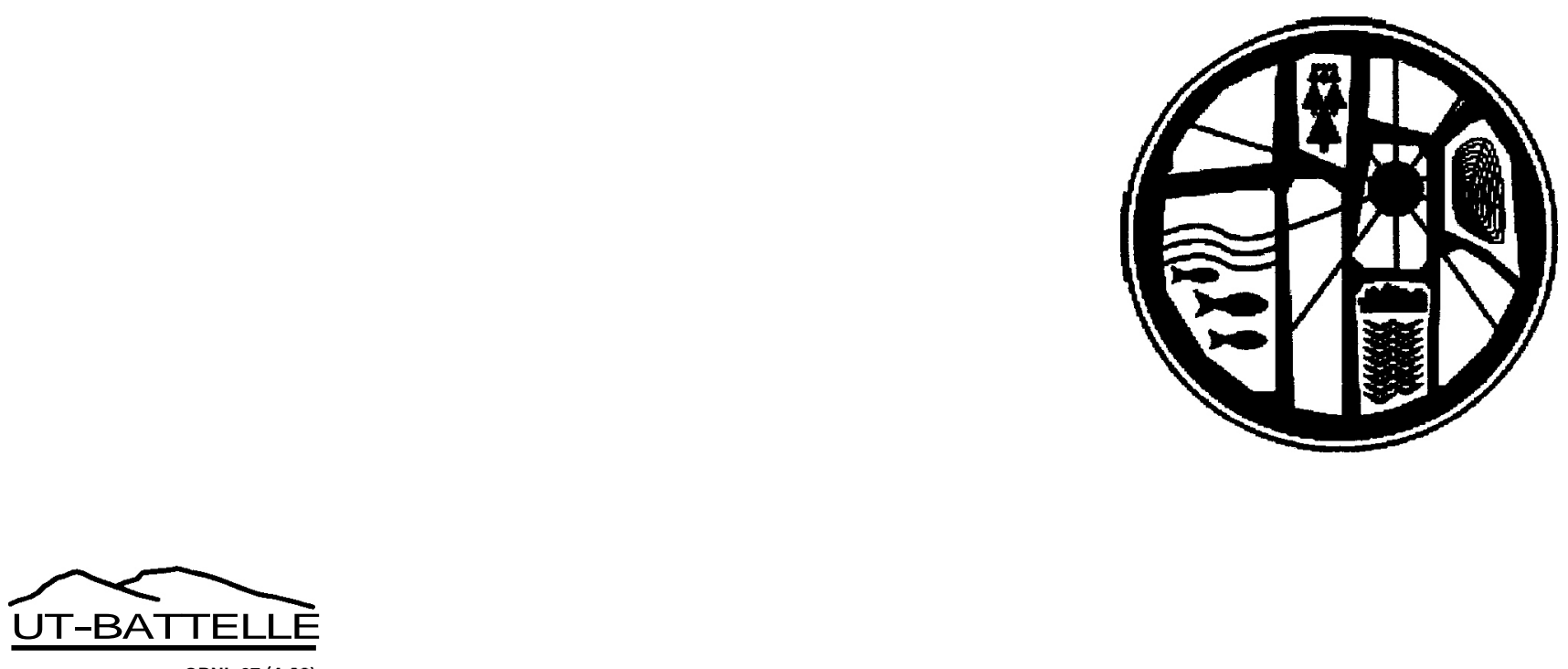
Available tronically from the following source.

Web sitte: www.doe,gov/bridge

Reports are available in paper to the public from the following source.

U.S. Departmentof Commerce

National Technical Information Service

5285 Port Royal Road

Springfield, VA 22161

Telephone: 1-800-553-6847

TDD: 703-487-4639

Fax: 703-605-6900

E-mail: orders@ntis.fedworld.gov

Web site: www.ntis.gov/ordering.htm

Reports are available in paper to U.S. Department of Energy (DOE) employees, DOE contractors, Energy Technology Data Exchange (ETDE) representatives, and International Nuclear Information System (INIS) representativesfrom the following source.

Office of Scientific and Technical Information

P.O. Box 62

Oak Ridge, TN 37831

Telephone: 865-576-8401

Fax: 865-576-5728

E-mall: reports0adonis.osti,gov

Web site; http://www.osti.gov/products/sources.html

This report was prepared as an account of work sponsored by an agency of the United States government. Neither the United States government nor any agency thereof, nor any of their employees, makes any warranty, express or implied, or assumes any legal liability or responsibility for the accuracy, completeness, or usefulness of any information, apparatus, product, or process disclosed, or represents that its use would not infringe privately owned rights. Reference herein to any specific commercial product, process, or service by trade name, trademark, manufacturer, or otherwise, does not necessarily constitute or imply its endorsement, recommendation, or favoring by the United States government or any agency thereof. The views and opinions of authors expressed herein do not necessarily state or reflect those of the United States government or any agency thereof. 
Environmental Sciences Division

\title{
ASSESSMENT OF NONNATIVE INVASIVE PLANTS IN THE DOE OAK RIDGE NATIONAL ENVIRONMENTAL RESEARCH PARK
}

\author{
S. J. Drake \\ Botany Department \\ University of Georgia \\ Athens, Georgia \\ J. F. Weltzin \\ Department of Ecology and Evolutionary Biology \\ The University of Tennessee \\ Knoxville, Tennessee \\ P. D. Parr \\ Environmental Sciences Division \\ Oak Ridge National Laboratory \\ Oak Ridge, Tennessee
}

Date Published: October 2002

Prepared for the

U.S. Department of Energy

Office of Science

Budget Activity Number $\mathbf{2 4 0 0 0 0 0 0 0}$

Prepared by

OAK RIDGE NATIONAL LABORATORY

Oak Ridge, Tennessee 37831

managed by

UT-BATTELLE, LLC

for the

U.S. DEPARTMENT OFENERGY

under contract DE-AC05-000R22725 


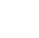




\section{CONTENTS}

Page

LIST OF TABLES.....................................................................................................................................

LIST OF FIGURES …................................................................................................................ v

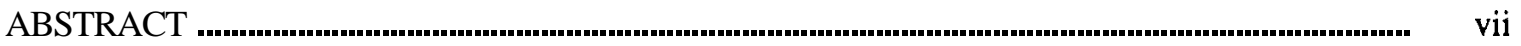

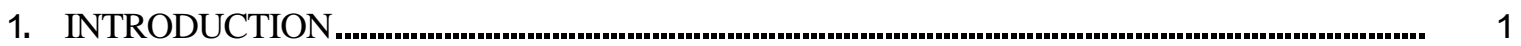

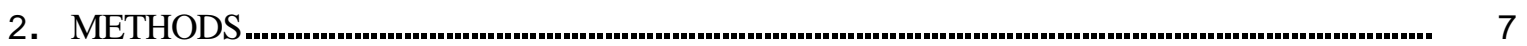

2.1 RESEARCHPARK SITE DESCRIPTION ................................................................................ 7

2.2 MANAGEMENT AREAS ON THE RESEARCHPARK ............................................................... 7

2.3 INDIVIDUAL MANAGEMENT AREA SITE DESCRIPTIONS ........................................... 9

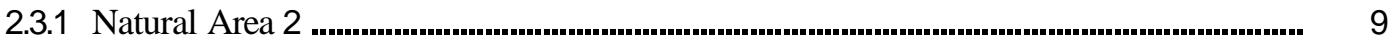

232 Natural Area 4 .................................................................................................................. 9

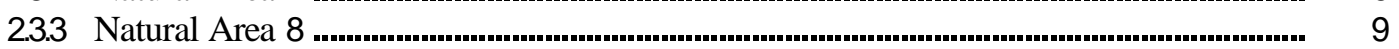

2.3.4 Natural Area 9 ................................................................................................................... 9

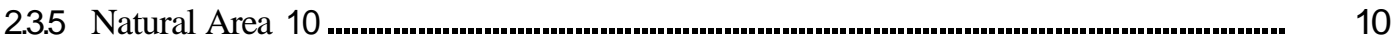

2.3.6 Natural Area 11 ................................................................................................................................ 10

2.3.7 Natural Area 13 ..................................................................................................................... 10

23.8 Natural Area 18 ..................................................................................................................... 10

2.3.9 Natural Area 20 .................................................................................................................... 11

2.3.10 Natural Area 21a ........................................................................................................... 11

2.3.11 Natural Area 24 ........................................................................................................ 11

2.3.12 Natural Area 42 ............................................................................................................... 11

2.3.13 Natural Area 43 ............................................................................................................................... 12

2.3.14 Natural Area 47 ...................................................................................................................... 12

2.3.15 Reference Area 8 ................................................................................................... 12

2.3.16 Walker Branch Watershed ............................................................................................... 12

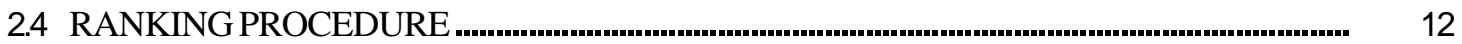

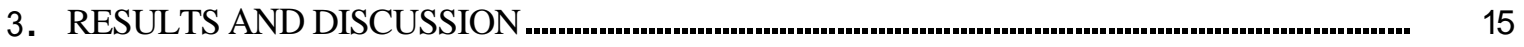

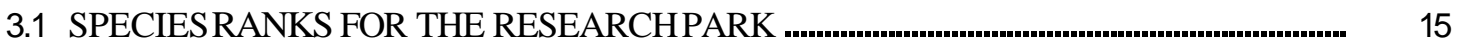

3.2 SPECIESRANKS FOR EACH MANAGEMENT AREA ........................................................ 18

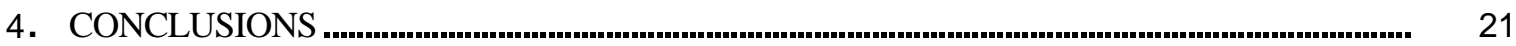

4.1 RANKING NONNATIVE, INVASIVEPLANTS ON THE RESEARCH PARK _._._._._. 21

4.2 THE NEED FOR ADDITIONAL RESEARCH ................................................................ 21

4.3 DEVELOPMENT OF MANAGEMENT STRATEGIESFOR THE RESEARCHPARK ...........22

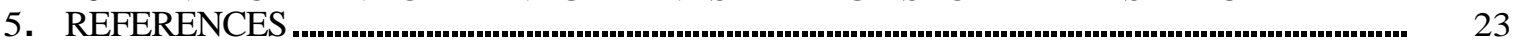

APPENDIX $\boldsymbol{A}$ NONNATIVE PLANT SPECIES ON THE RESEARCHPARK …........................... A $\quad$ A 1

APPENDIX B: AGGRESSIVE INVASIVE PLANT SPECIES ON THE RESEARCH PARK .............. B-1

APPENDIX C: ALIEN PLANTS RANKING SYSTEM, VERSION 5.1 ........................................ C-1

APPENDIX D: RESPONSES TO EACH RANKING SYSTEMQUESTION (QUESTIONS 1 THROUGH 23) FOR EACH SPECIES ON EACH MANAGEMENT AREA (MA) SURVEYED ON THE RESEARCHPARK

APPENDIXE: RESPONSES TO EACH RANKING SYSTEM QUESTION(QUESTIONS 1 THROUGH 23) FOR EACH SPECIES SURVEYED IN THE NATIONAL ENVIRONMENTAL RESEARCHPARK …..................................................... E. E APPENDIXF SPECIES ABSTRACTS FOR EACH SPECIES SURVEYED IN THIS STUDY ...........F.1 
. 


\section{LIST OF TABLES}

Table

1 The ten most aggressive invasive plants on the Research Park ranked by Awl and

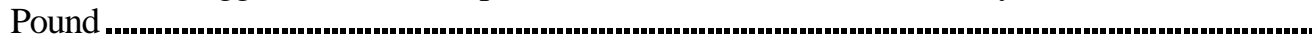

2 Ranking of invasive species in each management area, including Natural Areas (NA), Reference Area 8 (RA8), and Walker Branch Watershed (WBW) within the Research Park

3 Nonnative, invasive plants on the Research Park ranked by this study

\section{LIST OF FIGURES}

Figure

1 Research Park Areas surveyed for invasive plants 


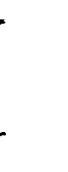




\begin{abstract}
The Department of Energy (DOE) National Environmental Research Park at Oak Ridge, Tennessee, is composed of second-growth forest stands characteristic of much of the eastern deciduous forest of the Ridge and Valley Province of Tennessee. Human use of natural ecosystems in this region has facilitated the establishment of at least $\mathbf{1 6 7}$ nonnative, invasive plant species on the Research Park. Our objective was to assess the distribution, abundance, impact, and potential for control of the $\mathbf{1 8}$ most abundant invasive species on the Research Park. In 2000, field surveys were conducted of 16 management areas on the Research Park (14 Natural Areas, 1 Reference Area, and Walker Branch Watershed) and the Research Park as a whole to acquire qualitative and quantitative data on the distribution and abundance of these taxa. Data from the surveys were used to rank the relative importance of these species using the "Alien Plant Ranking System, Version 5.1" developed by the U.S. Geological Survey. Microstegium (Microstegium vimineum) was ranked highest, or most problematic, for the entire Research Park because of its potential impact on natural systems, its tendency to become a management problem, and how difficult it is to control. Microstegium was present in $\mathbf{1 2}$ of the $\mathbf{1 6}$ individual sites surveyed; when present, it consistently ranked as the most problematic invasive species, particularly in terms of its potential impact on natural systems. Japanese honeysuckle(Lonicera japonica) and Chinese privet (Ligustrum sinense) were the second-and third-most problematic plant species on the Research Park; these two species were present in $\mathbf{1 2}$ and 9 of the $\mathbf{1 6}$ sites surveyed, respectively, and often ranked second- or third-most problematic. Other nonnative, invasive species, in decreasing rank order, included kudzu (Pueraria montma), multiflora rose (Rosa multiflora), Chinese lespedeza (Lespedeza cuneara), and other species representing a variety of life forms and growth forms. Results of this research can be used to prioritize management and research activities related to these invasive taxa on the Research Park as a whole and for specific Natural or Reference Areas. Additional research on the autecology and synecology of each species surveyed is suggested. In particular, research should focus on assessing the impacts of these species on the invaded plant and animal communities and ecosystems. Finally, this ranking system could be used to similarly rank the many other nonnative, invasive species present on the Research Park not included in this study.
\end{abstract}




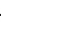




\section{INTRODUCTION}

Invasive plants are defined in this document as plants that are not native to an area and that may potentially displace or otherwise adversely affect native plant and animal species (Bowen 1996). Plants that are novel to a particular site or region may successfully establish and maintain relatively dense populations for several reasons. First, there may be a lack of natural growth inhibitors, such as predators, parasites, and diseases, at the site of introduction, thus allowing the nonnative plant to spread (White 1997). Second, invasive plants are often prolific seed producers, with seeds that may disperse widely and that may remain viable in the soil for long periods of time (Rejmanek and Richardson 1996). Alternatively, invasive plants may reproduce asexually through extensive root growth, suckering, and resprouting (White 1997). Invasive plants are often capable of producing larger and higher quality fruit than native congeners, thus making them a better food source for animals and birds that may aid in their dispersal. For example, common hawthorn (Crataegus monogyna) has rapidly become established throughout portions of western Oregon because its seeds have been carried great distances by birds (Sallabanks 1993).

Invasive plants tend to be most problematic in disturbed areas (Vitousek 1990). Kudzu (Pueraria montana) is a notorious invader of roadsides and power transmission line rights-of-way in the southeastern United States, but it is seldom found in adjacent, lessdisturbed habitats (Plant Conservation Alliance 1997). In contrast, some invasive plants are capable of establishing in relatively undisturbed sites. For example, microstegium (Microstegiurnvirnineurn) appears to invade forests that have been undisturbed for decades (Barden 1987, Redman 1995).

Invasive plants are often the target of management activities designed to eradicate them, or control their spread, in order to minimize their impact on existing ecological systems. However, management activities are often hampered by limited funds, time, and personnel. Even if adequate resources were available, managers may lack information about the natural history of the many different species in question and knowledge about the potential impacts that each species may have. Further, depending on the region and the management area in question, there may be numerous invasive species all deserving of management attention. For example, surveys of the flora at the Oak Ridge National Environmental Research Park in Tennessee have documented 167 nonnative, invasive species to date (Appendix A). Thus, managers need to prioritize their activities to focus on those species that may pose the greatest threat to existing management goals.

The 167 nonnative, invasive species on the Research Park (hereafter Research Park) are classified as "aggressive," "questionably aggressive," "passive," and "questionably passive" based on their abundance, distribution, and a qualitative assessment of their tendency to exclude native plant species (Awl et al. 1996). However, the relative importance of taxa within each classification has not been determined.

Forty-two of the 167 invasive species are classified as "aggressive" (listed in Appendix B). Awl (Tennessee Valley Authority, May 2000, personal communication)identified $\mathbf{1 0}$ of these aggressive invasive species for which basic information on the distribution and abundance were available for the Research Park. She then prioritized them in terms of management using a quantitative ranking system developed by the National Park Service (Table 1). Although purple loosestrife (Lythrum salicaria) was ranked relatively low in this original ranking because of its limited distribution, Awl moved it to the top of the list because of its potential to spread from its single location of Occurrence on the Research Park. 
Table 1. The ten most aggressive invasive plants on the Research Park ranked by Awl and Pounds (unpublishedmanuscript)

\begin{tabular}{lcc}
\hline Scientific name & Common name & Rank \\
\hline Lythrum salicaria & Purple loosestrife & 1 \\
Pueraria montana & Kudzu & 2 \\
Elaeagnus umbellata & Autumn olive & 3 \\
Ligustrum sinense & Chinese privet & 4 \\
Ailanthus altissima & Tree-of-heaven & 5 \\
Celastrus orbiculatus & Oriental bittersweet & 6 \\
Microstegium vimineum & Microstegium(Japanese grass) & 7 \\
Lonicerajaponica & Japanese honeysuckle & 8 \\
Rosa multiflora & Multiflorarose & 9 \\
Sorghum halepense & Johnsongrass & 10 \\
\hline
\end{tabular}

The goal of our research was to determine the relative importance of 18 of the most abundant or widespread invasive species on the Research Park in terms of their potential impact on natural systems, their tendency to become management problems, and their potential for control. The 18 species ranked herein include nine of the ten taxa previously ranked by Awl (Tennessee Valley Authority, May 2000, personal communication) and nine additional species widely distributed throughout the Research Park (Table 2). Purple loosestrife was excluded from the analysis because it has been practically eradicated from the one site it occupied at the time of Awl's original investigation (Pounds, L. R., ORNL Consultant, 2000, personal communication). The nine species new to this analysis include Chinese yam (Dioscorea batatas), periwinkle (Vinca minor), field garlic (Allium vineale), Chinese lespedeza (Lespedeza cuneata), spearmint (Mentha spicatu), bull thistle (Cirsium vulgare), crown vetch (Coronilla varia), empress tree (Paulownia tomentosa), and watercress (Nasturtium officinale).

Table 2. Ranking of invasive species in each management area, including Natural Areas (NA), Reference Area 8 (RA8), and Walker Branch Watershed (WBW) within the Research Park

Raw scores for each section of the ranking system (i.e., potential impact on natural systems, its tendency to become a management problem or pest, and how difficult it is to control) are summed to provide a total raw score. The final rank, where 1 is most problematic overall, was assigned based on the total raw score.

\begin{tabular}{|c|c|c|c|c|c|c|c|}
\hline Area & Scientificname & Commonname & Impact & Pest & Control & Total & Rank \\
\hline \multirow[t]{7}{*}{ NA2 } & $\begin{array}{l}\text { Microstegium } \\
\text { vimineum }\end{array}$ & Japanese grass & 56 & 71 & 24 & 151 & 1 \\
\hline & $\begin{array}{c}\text { Ligustrum } \\
\text { sinense }\end{array}$ & Chinese privet & 33 & 70 & 24 & 127 & 2 \\
\hline & $\begin{array}{l}\text { Lonicera } \\
\text { japonica }\end{array}$ & $\begin{array}{c}\text { Japanese } \\
\text { honeysuckle }\end{array}$ & 31 & 60 & 29 & 120 & 3 \\
\hline & $\begin{array}{l}\text { Lespedeza } \\
\text { cuneata }\end{array}$ & Chinese lespedeza & 22 & 59 & 16 & 97 & 4 \\
\hline & $\begin{array}{l}\text { Celastrus } \\
\text { orbiculatus }\end{array}$ & Oriental bittersweet & 31 & 30 & 19 & 80 & 5 \\
\hline & $\begin{array}{l}\text { Ailanthus } \\
\text { altissima }\end{array}$ & Tree-of-heaven & 13 & 48 & 13 & 74 & 6 \\
\hline & $\begin{array}{l}\text { Elaeagnus } \\
\text { umbellata }\end{array}$ & Autumn olive & 9 & 51 & 13 & 73 & 7 \\
\hline
\end{tabular}


Table 2 (continued)

\begin{tabular}{|c|c|c|c|c|c|c|c|}
\hline Area & Scientificname & Commonname & Impact & Pest & Control & Total & Rank \\
\hline \multirow[t]{6}{*}{ NA4 } & $\begin{array}{l}\text { Microstegium } \\
\text { vimineum }\end{array}$ & Japanese grass & 56 & 71 & 24 & 151 & 1 \\
\hline & $\begin{array}{c}\text { Ligustrum } \\
\text { sinense }\end{array}$ & Chinese privet & 33 & 70 & 21 & 124 & 2 \\
\hline & $\begin{array}{l}\text { Lespedeza } \\
\text { cuneata }\end{array}$ & Chinese lespedeza & 31 & 49 & 32 & 112 & 3 \\
\hline & $\begin{array}{c}\text { Dioscorea } \\
\text { batatas }\end{array}$ & Chinese yam & 44 & 37 & 11 & 92 & 4 \\
\hline & $\begin{array}{l}\text { Paulownia } \\
\text { tomentosa }\end{array}$ & Empress tree & 11 & 54 & 9 & 74 & 5 \\
\hline & Coronilla varia & Crown vetch & 13 & 17 & 7 & 37 & 6 \\
\hline \multirow[t]{4}{*}{ NA8 } & $\begin{array}{c}\text { Lespedeza } \\
\text { cuneata }\end{array}$ & Chinese lespedeza & 36 & 59 & 32 & 127 & 1 \\
\hline & $\begin{array}{l}\text { Lonicera } \\
\text { japonica }\end{array}$ & $\begin{array}{c}\text { Japanese } \\
\text { honeysuckle }\end{array}$ & 29 & 60 & 21 & 110 & 2 \\
\hline & $\begin{array}{l}\text { Ligustrum } \\
\text { sinense }\end{array}$ & Chinese privet & 18 & 70 & 20 & 108 & 3 \\
\hline & $\begin{array}{l}\text { Pueraria } \\
\text { montana }\end{array}$ & Kudzu & 45 & 35 & 24 & 104 & 4 \\
\hline \multirow[t]{2}{*}{ NA9 } & $\begin{array}{l}\text { Microstegium } \\
\text { vimineum }\end{array}$ & Japanese grass & 64 & 67 & 37 & 168 & 1 \\
\hline & $\begin{array}{c}\text { Lonicera } \\
\text { japonica }\end{array}$ & $\begin{array}{c}\text { Japanese } \\
\text { honeysuckle }\end{array}$ & 29 & 56 & 24 & 109 & 2 \\
\hline \multirow[t]{5}{*}{ NA10 } & $\begin{array}{l}\text { Microstegium } \\
\text { vimineum }\end{array}$ & Japanese grass & 64 & 67 & 37 & 168 & 1 \\
\hline & $\begin{array}{c}\text { Lespedeza } \\
\text { cuneata }\end{array}$ & Chinese lespedeza & 36 & 59 & 32 & 127 & 2 \\
\hline & $\begin{array}{l}\text { Lonicera } \\
\text { japonica }\end{array}$ & $\begin{array}{c}\text { Japanese } \\
\text { honeysuckle }\end{array}$ & 29 & 56 & 24 & 109 & 3 \\
\hline & $\begin{array}{c}\text { Dioscorea } \\
\text { batatas }\end{array}$ & Chinese yam & 35 & 37 & 11 & 83 & 4 \\
\hline & $\begin{array}{l}\text { Paulownia } \\
\text { tomentosa }\end{array}$ & Empress twe & 11 & 54 & 9 & 74 & 5 \\
\hline \multirow[t]{4}{*}{ NA11 } & $\begin{array}{l}\text { Microstegium } \\
\text { vimineum }\end{array}$ & Japanese grass & 51 & 63 & 16 & 130 & 1 \\
\hline & Rosa multiflora & Multiflora rose & 29 & 54 & 27 & 110 & 2 \\
\hline & $\begin{array}{l}\text { Lonicera } \\
\text { japonica }\end{array}$ & $\begin{array}{c}\text { Japanese } \\
\text { honeysuckle }\end{array}$ & 29 & 56 & 24 & 109 & 3 \\
\hline & $\begin{array}{c}\text { Ligustrum } \\
\text { sinense }\end{array}$ & Chinese privet & 18 & 65 & 20 & 103 & 4 \\
\hline \multirow[t]{2}{*}{ NA13 } & $\begin{array}{l}\text { Microstegium } \\
\text { viminewn }\end{array}$ & Japanese grass & 64 & 71 & 37 & 172 & 1 \\
\hline & $\begin{array}{c}\text { Lonicera } \\
\text { japonica }\end{array}$ & $\begin{array}{c}\text { Japanese } \\
\text { honeysuckle }\end{array}$ & 29 & 56 & 24 & 109 & 2 \\
\hline
\end{tabular}


Table 2 (continued)

\begin{tabular}{|c|c|c|c|c|c|c|c|}
\hline Area & Scientificname & Commonname & Impact & Pest & Control & Total & Rank \\
\hline & $\begin{array}{c}\text { Lespedeza } \\
\text { cuneata }\end{array}$ & Chinese lespedeza & 25 & 54 & 20 & 99 & 3 \\
\hline & $\begin{array}{c}\text { Dioscorea } \\
\text { batatas }\end{array}$ & Chinese yam & 49 & 38 & 4 & 91 & 4 \\
\hline & $\begin{array}{l}\text { Elaeagnus } \\
\text { umbellata }\end{array}$ & Autumn olive & 18 & 51 & 13 & 82 & 5 \\
\hline & Vinca minor & Periwinkle & 29 & 13 & 11 & 53 & 6 \\
\hline \multirow[t]{6}{*}{ NA18 } & $\begin{array}{l}\text { Microstegium } \\
\text { vimineum }\end{array}$ & Japanese grass & 64 & 71 & 37 & 172 & 1 \\
\hline & $\begin{array}{c}\text { Lespedeza } \\
\text { cuneata }\end{array}$ & Chinese lespedeza & 36 & 48 & 32 & 116 & 2 \\
\hline & $\begin{array}{l}\text { Lonicera } \\
\text { japonica }\end{array}$ & $\begin{array}{c}\text { Japanese } \\
\text { honeysuckle }\end{array}$ & 29 & 56 & 24 & 109 & 3 \\
\hline & $\begin{array}{l}\text { Paulownia } \\
\text { tomentosa }\end{array}$ & Empress tree & 11 & 49 & 9 & 69 & 4 \\
\hline & Vinca minor & Periwinkle & 29 & 13 & 7 & 49 & 5 \\
\hline & Cirsium vulgare & Bull thistle & 9 & 27 & 4 & 40 & 6 \\
\hline \multirow[t]{10}{*}{ NA20 } & $\begin{array}{l}\text { Microstegium } \\
\text { vimineum }\end{array}$ & Japanese grass & 45 & 71 & 20 & 136 & 1 \\
\hline & $\begin{array}{c}\text { Ligustrum } \\
\text { sinense }\end{array}$ & Chinese privet & 36 & 70 & 20 & 126 & 2 \\
\hline & $\begin{array}{l}\text { Lespedeza } \\
\text { cuneata }\end{array}$ & Chinese lespedeza & 27 & 48 & 23 & 98 & 3 \\
\hline & Rosa multiflora & Multiflora rose & 25 & 48 & 24 & 97 & 4 \\
\hline & $\begin{array}{l}\text { Pueraria } \\
\text { montana }\end{array}$ & Kudzu & 45 & 35 & 17 & 97 & 5 \\
\hline & $\begin{array}{c}\text { Ailanthus } \\
\text { altissima }\end{array}$ & Tree-of-heaven & 16 & 51 & 15 & 82 & 6 \\
\hline & $\begin{array}{l}\text { Dioscorea } \\
\text { batatas }\end{array}$ & Chinese yam & 35 & 32 & 11 & 78 & 7 \\
\hline & Vincaminor & Periwinkle & 29 & 13 & 8 & 50 & 8 \\
\hline & Cirsium vulgare & Bull thistle & 9 & 24 & 4 & 37 & 9 \\
\hline & $\begin{array}{c}\text { Sorghum } \\
\text { halepense }\end{array}$ & Johnsongrass & 9 & 8 & 4 & 21 & 10 \\
\hline \multirow[t]{5}{*}{ NA 21a } & $\begin{array}{l}\text { Microstegium } \\
\text { vimineum }\end{array}$ & Japanese grass & 56 & 67 & 37 & 160 & 1 \\
\hline & $\begin{array}{l}\text { Ligustrum } \\
\text { sinense }\end{array}$ & Chinese privet & 47 & 70 & 40 & 157 & 2 \\
\hline & $\begin{array}{l}\text { Lonicera } \\
\text { japonica }\end{array}$ & $\begin{array}{c}\text { Japanese } \\
\text { honeysuckle }\end{array}$ & 45 & 60 & 33 & 138 & 3 \\
\hline & Rosa multiflora & Multiflora rose & 35 & 60 & 31 & 126 & 4 \\
\hline & $\begin{array}{l}\text { Elaeagnus } \\
\text { umbellata }\end{array}$ & Autumn olive & 29 & 37 & 24 & 90 & 5 \\
\hline NA24 & Mentha spicata & Spearmint & 29 & 25 & 13 & 67 & 1 \\
\hline
\end{tabular}


Table 2 (continued)

\begin{tabular}{|c|c|c|c|c|c|c|c|}
\hline Area & Scientificname & Commonname & Impact & Pest & Control & Total & Rank \\
\hline \multirow[t]{5}{*}{$\mathrm{NA} 42$} & $\begin{array}{l}\text { Microstegium } \\
\text { vimineum }\end{array}$ & Japanese grass & 56 & 67 & 37 & 160 & 1 \\
\hline & $\begin{array}{c}\text { Lonicera } \\
\text { japonica }\end{array}$ & $\begin{array}{c}\text { Japanese } \\
\text { honeysuckle }\end{array}$ & 45 & 56 & 33 & 134 & 2 \\
\hline & Rosa multiflora & Multiflora rose & 35 & 60 & 31 & 126 & 3 \\
\hline & $\begin{array}{c}\text { Dioscorea } \\
\text { batatas }\end{array}$ & Chinese yam & 53 & 43 & 24 & 120 & 4 \\
\hline & $\begin{array}{l}\text { Lespedeza } \\
\text { cuneata }\end{array}$ & Chinese lespedeza & 35 & 51 & 29 & 115 & 5 \\
\hline \multirow[t]{7}{*}{ NA43 } & $\begin{array}{l}\text { Ligustrum } \\
\text { sinense }\end{array}$ & Chinese privet & 31 & 70 & 29 & 130 & 1 \\
\hline & Rosa multiflora & Multiflorarose & 35 & 60 & 31 & 126 & 2 \\
\hline & $\begin{array}{l}\text { Lespedeza } \\
\text { cuneata }\end{array}$ & Chinese lespedeza & 33 & 51 & 36 & 120 & 3 \\
\hline & $\begin{array}{l}\text { Lonicera } \\
\text { japonica }\end{array}$ & $\begin{array}{c}\text { Japanese } \\
\text { honeysuckle }\end{array}$ & 36 & 56 & 23 & 115 & 4 \\
\hline & Allium vineale & Field garlic & 45 & 29 & 28 & 102 & 5 \\
\hline & $\begin{array}{l}\text { Elaeagnus } \\
\text { umbellata }\end{array}$ & Autumn olive & 22 & 37 & 17 & 76 & 6 \\
\hline & $\begin{array}{l}\text { Nasturtium } \\
\text { oflcinale }\end{array}$ & Watercress & 13 & 21 & 7 & 41 & 7 \\
\hline \multirow[t]{11}{*}{ NA47 } & $\begin{array}{l}\text { Microstegium } \\
\text { vimineum }\end{array}$ & Japanese grass & 58 & 67 & 40 & 165 & 1 \\
\hline & $\begin{array}{l}\text { Ligustrum } \\
\text { sinense }\end{array}$ & Chinese privet & 47 & 70 & 40 & 157 & 2 \\
\hline & $\begin{array}{l}\text { Lonicera } \\
\text { japonica }\end{array}$ & $\begin{array}{c}\text { Japanese } \\
\text { honeysuckle }\end{array}$ & 55 & 52 & 33 & 140 & 3 \\
\hline & Rosa multiflora & Multiflorarose & 35 & 63 & 31 & 129 & 4 \\
\hline & $\begin{array}{c}\text { Dioscorea } \\
\text { batatas }\end{array}$ & Chinese yam & 53 & 43 & 24 & 120 & 5 \\
\hline & $\begin{array}{l}\text { Lespedeza } \\
\text { cuneata }\end{array}$ & Chinese lespedeza & 36 & 51 & 32 & 119 & 6 \\
\hline & $\begin{array}{l}\text { Ailanthus } \\
\text { altissima }\end{array}$ & Tree-of-heaven & 22 & 59 & 21 & 102 & 7 \\
\hline & $\begin{array}{l}\text { Elaeagnus } \\
\text { umbellata }\end{array}$ & Autumn olive & 22 & 37 & 17 & 76 & 8 \\
\hline & Vinca minor & Periwinkle & 29 & 21 & 21 & 71 & 9 \\
\hline & $\begin{array}{c}\text { Nasturtium } \\
\text { oflcinale }\end{array}$ & Watercress & 13 & 21 & 7 & 41 & 10 \\
\hline & Cirsium vulgare & Bull thistle & 9 & 27 & 4 & 40 & 11 \\
\hline RA8 & $\begin{array}{l}\text { Lespedeza } \\
\text { cuneata }\end{array}$ & Chinese lespedeza & 45 & 51 & 32 & 128 & 1 \\
\hline
\end{tabular}


Table 2 (continued)

\begin{tabular}{|c|c|c|c|c|c|c|c|}
\hline Area & Scientificname & Commonname & Impact & Pest & Control & Total & Rank \\
\hline & $\begin{array}{c}\text { Ligustrum } \\
\text { sinense }\end{array}$ & Chinese privet & 22 & 67 & 27 & 116 & 2 \\
\hline & Allium vineale & Field garlic & 25 & 41 & 24 & 90 & 3 \\
\hline & $\begin{array}{c}\text { Sorghum } \\
\text { halepense }\end{array}$ & Johnsongrass & 9 & 8 & 15 & 32 & 4 \\
\hline \multirow[t]{4}{*}{ WBW } & $\begin{array}{l}\text { Microstegium } \\
\text { vimineum }\end{array}$ & Japanese grass & 56 & 67 & 37 & 160 & 1 \\
\hline & $\begin{array}{c}\text { Lonicera } \\
\text { japonica }\end{array}$ & $\begin{array}{c}\text { Japanese } \\
\text { honeysuckle }\end{array}$ & 45 & 51 & 28 & 124 & 2 \\
\hline & $\begin{array}{c}\text { Lespedeza } \\
\text { cuneata }\end{array}$ & Chinese lespedeza & 33 & 51 & 28 & 112 & 3 \\
\hline & Vinca minor & Periwinkle & 29 & 21 & 24 & 74 & 4 \\
\hline
\end{tabular}

The research objectives were to rank these 18 species for (1)the entire Research Park and (2) each of 16 important management areas on the Research Park. Data for ranking were collected using field surveys and a review of the literature. We used a different ranking system than that previously employed by Awl (Tennessee Valley Authority, May 2000, personal communication) that was developed by the U.S. Geological Survey and termed the "Alien Plant Ranking System" (APRS Implementation Team 2000). 


\section{METHODS}

\subsection{RESEARCH PARK SITE DESCRIPTION}

The Oak Ridge National Environmental Research Park is located on the 13,860ha (34,241acre) Department of Energy Oak Ridge Reservation in Anderson and Roane counties, Tennessee (Fig. 1. The Research Park is situated within the Ridge and Valley Province west of the Appalachian Mountains (ORNL 2002). This region is characterized by roughly parallel ridges and valleys formed within the folds of Paleozoic sediments. The ridge and valley topography results from differentialerosion of alternating layers of resistant sandstone and less-resistant limestone (McKnight 1997) . This geologic pattern results in the many caves and sinkholes that can be found on the Research Park.

The Ridge and Valley Province is located within the Temperate Mesophytic Forest Region (Daubenmire 1978) . Upland sites are characterized by second-and third-growth oak-hickory forest stands, with Quercus spp., Carya spp., and Acer spp. the dominant overstory species. Stands of pines (Pinus echinata, $P$. virginiana, $P$. taeda) occupy ridges, abandoned agriculture fields, and pine plantations. Mesophytic hardwoods (Tilia, Liriodendron) dominate the lower slopes.

Climate in this region is characterized by cold winters and long frost-free summers. Mean annual temperature is about $14^{\circ} \mathrm{C}$, and mean annual precipitation is about $1300 \mathrm{~mm}$ (Hanson et al. 1998) . Soils are generally acidic and well weathered and are classified primarily as typic paleudults (Hanson et al. 1998) .

\subsection{MANAGEMENT AREAS ON THE RESEARCH PARK}

A total of 16 management areas, including Research Park Natural Areas, a Research Park Reference Area, and the Walker Branch Watershed, were selected for detailed field surveys (Fig. 1. Research Park Natural Areas were established to protect state-listed or federally listed rare species that occur on the Oak Ridge Reservation (Pounds, Parr, and Ryon 1993). Fourteen areas, representing a variety of habitats distributed throughout the Research Park, were selected for the survey. Natural Areas surveyed included mesic deciduous forest, palustrine forested wet-lands, a palustrine emergent marsh, limestone outcrops, and power transmission line rights-of-way.

Research Park Reference Areas are vegetational communities representative of the southern Appalachian region or sites that possess unique biotic features ((Pounds, Parr, and Ryon 1993) . The single Reference Area surveyed in this study, a cedar glade or barren on a limestone outcrop, was selected because it is a unique example of this plant community type on the Research Park and because it contains plant taxa uncommon to the region (e.g., Yucca spp. and Opuntia spp.).

Walker Branch Watershed is a research watershed that consists of two subcatchments with a total area of approximately 100 ha. Similar to other upland sites on the Research Park, the watershed is dominated by second-and third-growth oak-hickory, pine, and mesophytic hardwood forests that have established on former pastures or croplands. The underlying soils are acidic, very cherty, infertile, and quite permeable to water. There is a long and relatively well-known history of anthropogenic disturbance and research on the site, which is one of a few sites in the world characterized by long-term, intensive environmental studies at the watershed scale (Johnson and Van Hook 1989). Taxonomic nomenclature is from Wofford and Kral (1993). 


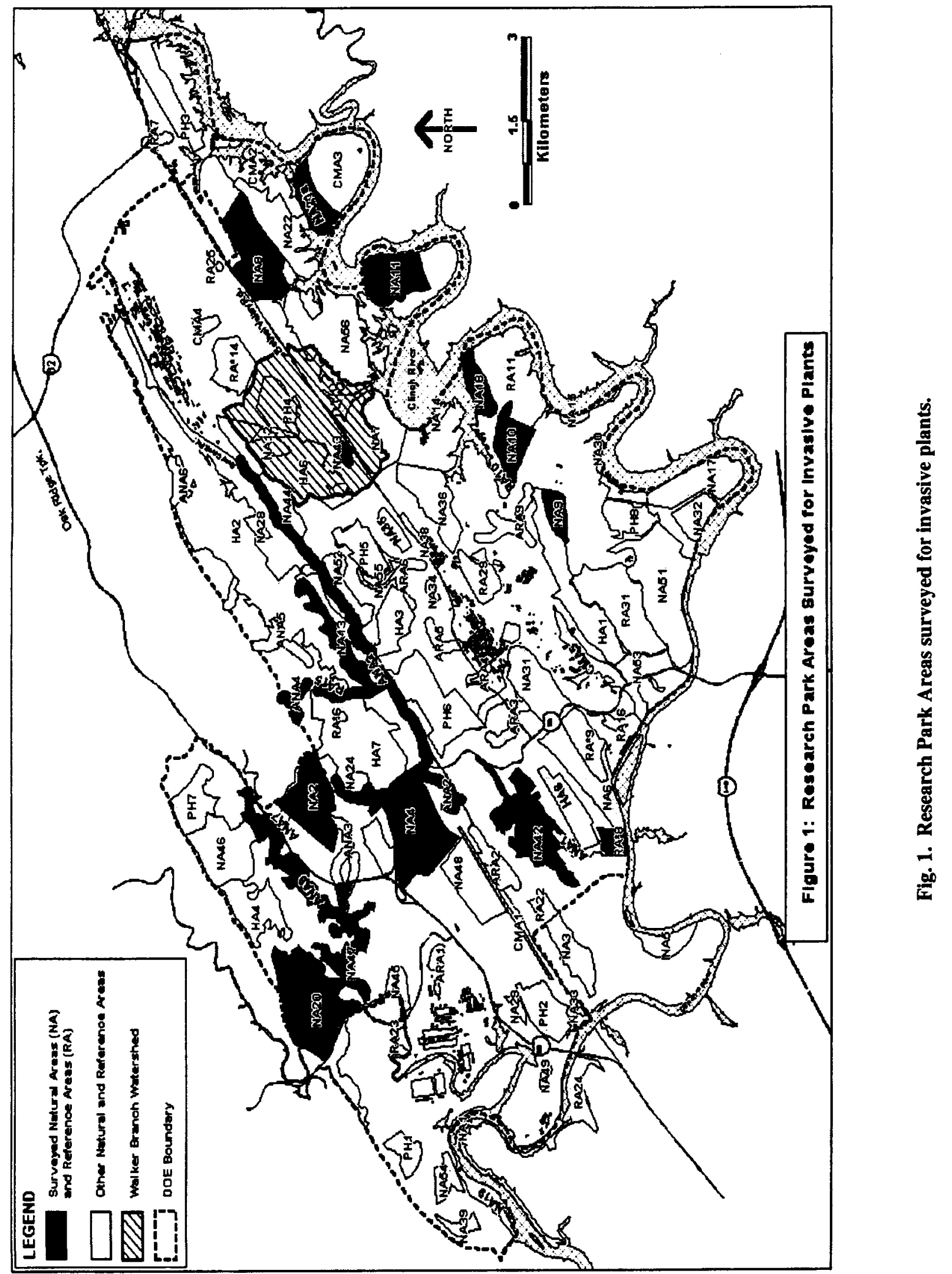




\section{INDIVIDUAL MANAGEMENT AREA SITE DESCRIPTIONS}

\subsection{Natural Area 2}

Natural Area 2 is located along U.S. Highway 95 between Hot Yard Road and Midway Turnpike (Fig. 1). This moist woodland contains a variety of tree species, including basswood (Tilia americana), beech (Fagus grandifolia), and maple (Acer spp.). Natural Area 2 contains goldenseal (Hydrastis canadensis)and Canada lily (Lilium canadense) (Pounds, Parr, and Ryon 1993; Cunninghamet al. 1993), which are listed as "Threatened Species" by the Tennessee Department of Environment and Conservation (TDEC). Microstegium is abundant throughout the site and forms a dense mat in the understory of this mid-successional forest. Chinese lespedeza (Lespedeza cuneata) and Japanese honeysuckle (Lonicera japonica) grow all along the length of the road. Japanese honeysuckle is especially abundant along the northeastern boundary of the Natural Area where a fence separates the Research Park from an adjacent neighborhood. Autumn olive (Elaeagnus umbellata), tree-of-heaven (Ailanthus altissima), and Chinese privet (Ligustrum sinense) also grow along the road but occur in smaller patches. Removal of a patch of oriental bittersweet (Celastrus orbiculatus) was initiated in July 2000 and continued in July 2001 by groups of high school teachers through the Appalachian Regional Commission Summer Research Program. The plants were either pulled up by hand or cut with a saw and treated with a glyphosate herbicide.

\section{Natural Area 4}

Natural Area 4, or Rein-Orchid Swamp, is a forested wetland at the intersection of Highway 95 and the Oak Ridge Turnpike (Fig. 1). The wetland is bordered by streams, a highway, and a power transmission line right-of-way that could each facilitate plant invasions. The wetland contains the northern tubercled rein-orchid (Platanthera flava var. herbiola), which is listed by TDEC, and the golden club (Orontiurnaquaticurn), which is uncommon to wetlands of the region (Pounds, Parr, and Ryon 1993; Cunninghamet al. 1993). Microstegium, Chinese yam (Dioscoreabatatas), and Chinese privet are abundant throughout the Natural Area but occur in larger patches along the stream that bisects the area. Several empress trees (Paulownia tomentosa) are present along the road. Chinese lespedeza is also abundant along the road as well as within the power transmission line right-of-way. Crown vetch (Coronillavaria) occurs for many meters along the grassy margin between the Natural Area and Highway 95.

\section{Natural Area 8}

Natural Area 8 is located in the McCoy Branch Embayment "Barren," just northwest of Freel's Bend (Fig. 1). The southern portion of this embayment consists of secondary forest. Invasive plants include a large patch of kudzu (Puerariamontana), which grows along the road, and Japanese honeysuckle, which occurs throughout this area. Chinese privet is present but uncommon. The northern portion of this embayment consists of a power transmission right-ofway that is mowed annually. Also a registered State Natural Area, this site contains the TDEClisted endangered tall larkspur (Delphiniumexaltatum) (Pounds, Parr, and Ryon 1993; Cunningham et al. 1993). The only invasive plant observed in the right-of-way was Chinese lespedeza, which grew amongst and adjacent to the tall larkspur.

\subsection{Natural Area 9}

Natural Area 9, or Cesium Forest Orchid Area, is located on Copper Ridge. This immature, mesic forest is dominated by tulip poplar (Liriodendron tulipifera). The uncommon lesser 
ladies'-tresses orchid (Spiranthes ovalis) is present in one of the sinks in this area (Pounds, Parr, and Ryon 1993). Invasive plants include large and dense patches of microstegium and Japanese honeysuckle that occur throughout the Natural Area.

\subsection{Natural Area 10}

Natural Area 10, known as Lazy Beaver Forest, is located on Copper Ridge in both Roane and Anderson counties. This Natural Area is a mesic forest dominated by tulip poplar and contains a TDEC threatened species, goldenseal (Hydrastis canadensis) as well as the uncommon lesser ladies'-tresses orchid (Pounds, Parr, and Ryon 1993). Dense carpets of microstegium and Chinese yam were observed near the roads. Empress tree and Chinese lespedeza are quite abundant in sunny areas. Japanese honeysuckle is present throughout the site in small amounts but is not a significant problem in this Natural Area.

\subsection{Natural Area 11}

Natural Area 11, or Bull Bluff, is a steep, limestone bluff with many cave entrances and sinkholes. This wooded slope contains the TDEC threatened species, Appalachian bugbane (Cimicifuga rubifolia) and northern bush-honeysuckle (Diervilla lonicera) (Pounds, Parr, and Ryon; Cunninghamet al. 1993). This Natural Area contains very few invasive plant species. Dense thickets of multiflora rose (Rosa multiflora)occur along the road adjacent to the site but are not expected to spread into the Natural Area because they require large amounts of sunlight. Microstegiumalso occurs in dense patches along the road and extends into the Natural Area for a few meters in several places. Honeysuckle was found throughout the site but in very minimal numbers. A single privet plant found on a tree root tip-up mound was removed during the survey in June 2000.

\subsection{Natural Area 13}

Natural Area 13 is located on Pine Ridge, east of Gum Branch Road and north of Bear Creek Road. Small streams that flow perpendicular to the area bisect Natural Area 13, which is characterized by forested floodplains and wetlands. A gravel road extends into the area and ends at a small cemetery where a patch of periwinkle (Vinca minor) can be found. TDEC-listed species that occur here include Canada lily and the northern tubercled rein-orchid (Pounds, Parr, and Ryon 1993; Cunningham et al. 1993). Extensive amounts of microstegium occur in the area and were observed growing alongside the northern tubercled rein-orchid.

\subsection{Natural Area 18}

Natural Area 18 is located on the eastern end of Copper Ridge and is bordered by a gravel road on one side and Melton Hill Lake on the other. This limestone outcrop area is rocky, and contains many sinkholes and caves (Pounds, Parr, and M. G. Ryon 1993). Microstegium, Chinese lespedeza, and periwinkle are most abundant along the road and waterfront but extend into the forest in smaller amounts. Microstegium is not present within the higher points of this area. In contrast, Japanese honeysuckle is abundant at these higher points, although it is scattered throughout the entire Natural Area. Several empress tree and bull thistle (Cirsium vulgare) populations occur in the road margins. 


\subsection{Natural Area 20}

Natural Area 20 is located on the slope of Black Oak Ridge along Poplar Creek. This area contains a few small limestone cliffs and is registered as a State Natural Area through a DOE/TDEC agreement. Many of the species that occur here are not common to the Research Park; they include spider lily (Hymenocallis ocidentalis) and fringe tree (Chionanthus virginicus). TDEC-listed species include pink lady's-slipper (Cypripedium acaule), which is considered threatened because it has experienced high levels of harvesting, and the threatened spreading false-foxglove (Aureolaria patula) (Pounds, Parr, and Ryon 1993; Cunningham et al. 1993). Chinese yam, privet, and multiflora rose grow along the road but have not apparently established within the Natural Area proper. There are dense stands of Chinese lespedeza, microstegium, and Johnson grass (Sorghum halepense) along the road. Bull thistle, tree-of-heaven, and kudzu were also noted along the road, and periwinkle is present in small amounts within the Natural Area. The North Boundary Road Greenway, open to the public, passes through a portion of this Natural Area.

\subsection{Natural Area 21a}

Natural Area 21a, or Rainy Knob Bluff, is located near Freel's Bend along Melton Hill Lake. This forested Natural Area is located on a hill and contains a large open limestone sinkhole. Carey saxifage (Saxifraga careyana) grows on the walls of the sinkhole. This species was recently removed from the list of species of special concern because its population has increased in recent years. Microstegium is especially abundant throughout the forest, whereas Chinese privet and multiflora rose, while still abundant, are less so than microstegium. The Chinese privet that is present is quite young and could easily be removed. Autumn olive was most abundant along the road at the edge of the Natural Area; however, several autumn olive plants were observed growing in the forest. Japanese honeysuckle is present in the Natural Area, but in minimal numbers.

\subsection{Natural Area 24}

Natural Area 24, or Hembree Marsh, is located between U.S.Highway 95 and Old County Road. This palustrine, emergent marsh is formed by perennial seeps and deep groundwater springs and is dominated by tall grasses, sedges, rushes, and other plants typical of such wetland systems in the region. It contains the fen orchid (Liparis loeselii), which is listed by TDEC as endangered (Pounds, Parr, and Ryon 1993; Cunninghamet al. 1993). Hembree Marsh is part of the Bear Creek $\mathrm{McNew}$ Hollow Floodplain, a registered State Natural Area. The only invasive species present in the marsh is a large patch of spearmint (Mentha spicatu), which occurs throughout the marsh.

\subsection{Natural Area 42}

Natural Area 42, known as New Zion Boggy Area, is located west of the intersection of Bethel Valley Road and Highway 95 on Chestnut Ridge near New Zion Cemetery. This 152-ha forested wetland is maintained by springs and often has patches of standing water throughout the year. TDEC-listed species that occur here include Pink lady's-slipper, Canada lily, and heavy sedge (Carex gravida). It was listed as RA20 until the TDEC-listed species were discovered there (Pounds, Parr, and Ryon 1993; Cunningham et al. 1993). Invasive species in the area include Chinese yam, microstegium, lespedeza, honeysuckle, and multiflora rose, especially on small upland islands and peninsulas throughout the wetland. 


\subsection{Natural Area 43}

Natural Area 43 is located along a power transmission line right-of-way, west of Walker Branch watershed and north of Bethel Valley Road. This area contains the state-listed tall larkspur (Delphiniumexaltatum) that grows along the hillside (Pounds, L. R., ORNL Consultant; P. D. Parr and M. G. Ryon, Oak Ridge National Laboratory; 2001, personal communication). Routine right-of-way maintenance includes periodic mowing to reduce the shoot extension of trees. Field garlic and Chinese lespedeza are abundant throughout the Natural Area, while Chinese privet, Japanese honeysuckle, autumn olive, and multiflora rose are abundant along the edges of the area and along the roadside. A small patch of watercress (Nasturtiumofficinale) occurs within a perennial stream crossing.

\subsection{Natural Area 47}

Natural Area 47 is located along the floodplain of East Fork Poplar Creek. This Natural Area encompasses 171 ha and contains canebreaks, which are patches of river bank dominated by native river cane (Arundinaria gigantea). The majority of the area contains a floodplain hardwood forest dominated by box elder, sycamore, and ash (Pounds, L. R., ORNL Consultant; P. D. Parr and M. G. Ryon, Oak Ridge National Laboratory; 2001, personal communication). Species listed by TDEC as threatened that occur in this area include golden seal, pink lady's. slipper, and ginseng (Panax quinquefolium). Numerous invasive plant species were observed in this Natural Area, including dense stands of Chinese privet. Other common invasive plant species that are abundant throughout the area include microstegium, Japanese honeysuckle, and Chinese yam. Chinese lespedeza, bull thistle, multiflora rose, and tree-of-heaven are profuse along the road. Autumn olive and periwinkle occur in small numbers throughout the area, and watercress was present in one location along a stream bank.

\subsection{Reference Area 8}

Reference Area 8 is a cedar barren limestone outcrop near Raccoon Creek. The area is very sunny, and the soil is thin and rocky, especially on steeper slopes. Red cedar (Juniperus virginiana), yucca (Yucca filamentosa), and prickly pear cactus (Opuntiahumifusa) are present (Pounds, Parr, and Ryon 1993). Chinese lespedeza is present in small numbers within the area, but it forms small, dense patches along the road. Johnson grass forms dense clumps along the road, and Chinese privet and field garlic are present along the road in smaller numbers.

\subsection{Walker Branch Watershed}

Walker Branch Watershed contains fewer invasive plants than many of the Natural Areas. Microstegium is present but is relatively uncommon; it is largely confined to access roads but forms small, scattered patches along ephemeral to perennial watercourses. Periwinkle forms dense stands along floodplains and at abandoned homesites. Lespedeza grows along many of the access roads, and Japanese honeysuckle is particularly prevalent in pine plantations.

\subsection{RANKING PROCEDURE}

A semiquantitativeranking system developed by the U.S. Geological Survey (APRS Implementation Team 2000) was used to rank the 18 nonnative subject species in this study. Generally, the "Alien Plants Ranking System" uses a query system to compile information about the characteristics of each invasive species, as well as the attributes of the invaded community. 
The rationale behind this approach is based on limited evidence that the invasion of a community by a nonnative plant species is controlled by the biological characteristics of the species in question, the number of propagules entering the community, and the susceptibility of the community to invasion (Lonsdale 1999). In turn, the susceptibility of a plant community to invasion is likely influenced by its disturbance regime, the competitive abilities of native species, and the prevailing climatic conditions (Lonsdale 1999).

The query list for each species consists of $\mathbf{2 3}$ "multiple-choice" questions arranged in three sections (Appendix C). Section I, "Significance of Threat or Impact (Site Characteristics)," is designed to determine the relative distribution and abundance of each species and its potential effect on native communities. Section II, "Innate Ability to Become a Pest," determines the autecological characteristics of the plant, and Section 111,"Difficulty of Control," describes the feasibility and effects of control measures. Responses to queries for the Research Park as a whole, and for each management area, are in Appendices D and E, respectively. Species abstracts are in Appendix F.

Queries in Section I (Significance of Threat or Impact and Site Characteristics)include the following:

1. Distribution relative to disturbance regime

2. Areal extent of populations

3. Numerical dominance of species within a community

4. Association with native community

5. Hybridization with native species

6. Degree of threat and impact

7. Effects on management goals

These queries were answered based on field surveys, interviews with managers knowledgeable about the sites and species, aerial photograph interpretation, and reviews of existing literature. Field surveys and interviews were conducted during the $\mathbf{2 0 0 0}$ growing season. Field surveys were conducted primarily to estimate the distribution and abundance of each species in each management area for queries 1 through 3. Field surveys were relatively extensive; more systematic, intensive surveys (e.g,, transects) were utilized as necessary in order to provide information sufficient to answer each query for each species. Species distributions relative to disturbanceregimes were determined based on the distribution of each species relative to the type, intensity, scale, and history of disturbance in the subject area. For example, microstegium and Japanese honeysuckle were often found in areas that have not been disturbed for at least 50 years, whereas Chinese lespedeza and field garlic were found growing in areas that are more disturbed by either roads or power line clearings.

Areal extents and numerical dominance were determined by estimating the proportion of each site occupied by each species. When determining the association of each species with native community, the response that best indicated the successional level of that portion of the management area that contained the species in question was selected. In contrast, when ranking each species within the Research Park as a whole, the response that best indicated the stand at the latest successional stage occupied by that species on the Research Park was selected. The potential for hybridization with native species was answered for each species based on reviews of the literature. Threats, impacts, and effects of each species on management goals were determined based on conversations with managers and scientists familiar with the area, coupled with observations of the density and distribution of each species at each site. 
Section II (Innate Ability to Become a Pest) includes the following ten questions:

8. Mode of reproduction

9. Vegetative reproduction

10. Frequency of sexual reproduction for mature plant

11. Number of seeds per plant

12. Dispersal ability

13. Germination requirements

14. Seedbanks

15. Competitive ability

16. Ecological effects

17. Known level of impact in natural areas

Answers to the first nine questions were based on reviews of the scientific literature. However, for most of our subject species, there is a paucity of data on competitive ability. Therefore we answered "unknown" for all species except kudzu. Similarly, the effects and impacts of these invasive species on native ecosystems are largely unknown, which mirrors the general dearth of scientific understanding of effects of invasive plants worldwide (Parker et al. 1999). Nonetheless, we estimated ecological effects and impacts based on reviews of the literature and our knowledge of the autecology and synecology of these species.

Section III (Difficulty of Control) includes the following six questions:

18. Likelihood of successfulcontrol

19. Saturation in surrounding region

20. Effectiveness of community management

21. Vegetative regeneration

22. Biological control

23. Side effects of control measures

These questions were answered through reviews of the literature, field observations, and interviews with managers familiar with physical, chemical, and biological control techniques. 


\section{RESULTS AND DISCUSSION}

\subsection{SPECIES RANKS FOR THE RESEARCH PARK}

Out of the 18 species ranked in this study, microstegium was identified as the most problematic nonnative, invasive plant on the Research Park as a whole (Table 3). Microstegium was ranked highest, or most problematic, because of its potential impact on natural systems, its tendency to become a management problem, and the difficulty of its control. Microstegium is present in numerous, dense stands across the Research Park, in both disturbed, early-successional habitats as well as relatively undisturbed, late-successional forest communities. In addition, it was present across a broad range of environmental conditions, from shallow flowing-water habitats to margins of gravel roads along dry ridge tops.

Table 3. Nonnative, invasive plants on the Research Park ranked by this study

Raw scores for each section of the ranking system (i.e., potential impact on natural systems, its tendency to become a management problem or pest, and how difficult it is to control) are summed to provide a total raw score. The final rank, where $\mathbf{1}$ is most problematic overall, was assigned based on the total raw score.

\begin{tabular}{lcccccc}
\hline Scientific name & Commonname & Impact & Pest & Control & Total & Rank \\
\hline Microstegium vimineum & Japanese grass & 60 & 67 & 44 & 171 & 1 \\
Lonicerajaponica & Japanese honeysuckle & 58 & 60 & 40 & 158 & 2 \\
Ligustrum sinense & Chinese privet & 44 & 70 & 33 & 147 & 3 \\
Pueraria Montana & Kudzu & 58 & 41 & 48 & 147 & 4 \\
Rosa multiflora & Multiflora rose & 36 & 59 & 35 & 130 & 5 \\
Lespedeza cuneata & Lespedeza & 36 & 59 & 33 & 128 & 6 \\
Dioscorea batatas & Chinese yam & 53 & 43 & 24 & 120 & 7 \\
Ailanthus altissima & Tree-of-heaven & 27 & 52 & 24 & 103 & 8 \\
Allium vineale & Field garlic & 24 & 38 & 31 & 93 & 9 \\
Elaeagnus umbellate & Autumn olive & 29 & 37 & 24 & 90 & 10 \\
Celastrus orbiculatus & Oriental bittersweet & 35 & 30 & 21 & 86 & 11 \\
Paulownia tomentosa & Empress tree & 18 & 46 & 19 & 83 & 12 \\
Sorghum halepense & Johnsongrass & 20 & 41 & 21 & 82 & 13 \\
Vinca minor & Penwinkle & 29 & 21 & 24 & 74 & 14 \\
Mentha spicata & Spearmint & 29 & 25 & 13 & 67 & 15 \\
Nasturtium officinale & Watercress & 22 & 21 & 7 & 50 & 16 \\
Cirsium vulgare & Bull thistle & 9 & 27 & 4 & 40 & 17 \\
Coronilla varia & Crown vetch & 13 & 17 & 7 & 37 & 18 \\
\hline
\end{tabular}

Although there is little published information about the effect that microstegium has on native plants and natural ecosystems, it has been suggested that it may exclude native plants or prevent them from becoming established (Barden 1987). Microstegium may become even more problematic in the near future; because it can reproduce vegetatively and from seed, it produces large number of seeds each year, and its seeds may remain viable in the soil for 3 or more years (USDA, NRCS 2001). In addition, control of microstegium populations is relatively difficult; successful control will likely require multiple applications of herbicide or labor-intensivehand pulling. However, small patches of microstegium have reportedly been controlled through a combination of herbicide application, mowing, and hand removal (K. Johnson, Great Smoky Mountains National Park, personal communication, 2001). Additional information on the autecology and synecology of microstegium is in Appendix F. 
Our ranking of microstegium is similar to other recent qualitative assessments of this particular species as a problematic invasive plant. For example, managers at the Great Smoky Mountains National Park in Tennessee and North Carolina have qualitatively ranked microstegium highest in potential impacts on natural ecosystems in the Park (out of a total of 35 problematic nonnative, invasive plants) and lowest in feasibility of control because so little is known of its autecology or synecology (National Park Service 1999). Similarly, 18 of 35 governmental and private agencies in the Southern Appalachian region reported that out of a total of 218 invasive plant species, microstegium was one of their greatest ongoing or potential management problems, behind only kudzu and multiflora rose (which were reported by 21 and 19 agencies, respectively) (Kuppinger 2000). Finally, the Tennessee Exotic Pest Plant Council considers microstegium in its "Rank 1, Severe Threat" category, which includes a total of 24 "exotic plant species which possess characteristics of invasive species and spread easily into native plant communities and displace native vegetation; includes species which are or could become widespread in Tennessee" (Tennessee Exotic Pest Plant Council 1996).

Japanese honeysuckle was ranked as the second-most problematic nonnative, invasive plant on the Research Park (Table 3). Japanese honeysuckle was present in numerous, dense stands across the Research Park in early-successional to mid-successional habitats. It was relatively uncommon on recently disturbed (e.g., bladed) habitats and was only patchily distributed in closed-canopy, later-successional forest communities. It was a common ground cover in more open habitats, such as decadent pine stands, along road margins, and in canopy gaps. Of the three ranking subcategories - potential impact on natural systems, tendency to become a management problem, and difficulty of control - it ranked second, second, and third highest in impact, management, and control, respectively.

Japanese honeysuckle is widely recognized as a problematic invasive plant throughout the region. It is in the Tennessee Exotic Pest Plant Council "Rank 1, Severe Threat" category (Tennessee Exotic Pest Plant Council 1996) and was reported by 17 of 35 management agencies in the Southern Appalachian region as an ongoing or potential management problem (Kuppinger 2000). Additional information on the natural history and control of Japanese honeysuckle is in Appendix F.

The third-most problematic plant surveyed on the Research Park was Chinese privet (Ligustrum sinense). It was most abundant along margins of gravel and paved roads, where it could form dense, unpenetrable stands with relatively dark understories. Although it can persist in shaded understory habitats, it was less abundant in relatively undisturbed, later-successional stands on the Research Park. It was also common in floodplains adjacent to streams and smaller watercourses but was occasionally present on drier upland sites. Chinese privet reproduces both vegetatively and by seed and produces copious quantities of fruits and seeds that are consumed and spread by birds. Although it vigorously resprouts from roots and cut stumps, it can be eradicated though a combination of top removal and application of glyphosate herbicide to the stump. Chinese privet is a "Rank 1, Severe Threat" species (Tennessee Exotic Pest Plant Council 1996) and was reported as a management problem by 16 of 35 management agencies in the Southern Appalachian region (Kuppinger 2000). Additional information on this and other invasive species ranked in this study is in Appendix F.

Kudzu was ranked the fourth-most problematic invasive plant on the Research Park (Table 3). This species is not widespread on the Research Park; in fact, it was present in only two management areas. However, it was ranked highest in terms of how difficult it is to control, largely because of its deep and extensive root system and tendency to resprout after physical 
manipulation. In addition, it ranked second-highest in terms of its potential impact on natural systems, because it is capable of overgrowing and decimating mature stands of trees. Because of this obvious tendency to overtop even tall vegetation, we assigned it a high competitive ability (query \# 15), whereas all other species were considered to have "unknown" competitive abilities because of insufficient data. In contrast with its potential impact and difficulty of control, it ranked relatively low (i.e., 10") for its tendency to become a management problem, because it does not tend to spread from site to site without human intervention. Further, it produces few viable seed, so it has little potential for long-distance dispersal outside of human activities.

Kudzu was the most commonly reported plant management problem (by 21 out of 35 management agencies) in the Southem Appalachian region, likely because of its widespread distribution, its obvious impact on natural systems, and its difficult nature to control (Kuppinger 2000). It is a "Rank 1, Severe Threat" species (TennesseeExotic Pest Plant Council 1996).

Multiflora rose was the fifth-most problematic plant (Table 3). This species was present along fence rows and in early to mid-successional habitats. Although it is somewhat shade-intolerant, small populations were present within closed-canopy forest. It was present across a broad range of edaphic and environmental conditions(i.e., dry ridges to mesic floodplains). When present, it often formed dense, impenetrable thickets. Its seeds are dispersed by wildlife, particularly birds, and its seeds remain viable in the soil for up to 20 years. Once established, it can resprout readily after top removal and can reproduce from roots and by layering. As such, it ranked relatively high in terms of its tendency to spread rapidly and become a management problem. Multiflora rose was reported as a management problem by resource managers in the Southern Appalachians more often than Japanese honeysuckle and microstegium, perhaps because its upright and clumped growth form make it relatively apparent on landscapes (Kuppinger 2000). It is classified as a noxious weed in several of the United States and is ranked as a "Severe Threat" to natural ecosystems in Tennessee (Tennessee Exotic Pest Plant Council 1996).

Chinese lespedeza ranked sixth in arr survey of invasive plants on the Research Park. Similar to field garlic (9") and Johnsongrass $\left(13^{\text {th }}\right)$, Chinese lespedeza tends to establish only in early successional sites with abundant sunlight. As such, it was present along roads, power transmission line rights-of-way, along waterfronts, and in other natural and human-made clearings and openings. When present, it can form dense thickets that may exclude small-statured (e.g., herbaceous) native plant species. Chinese lespedeza produces abundant seeds that are dispersed by wildlife, and its seeds remain viable in the soil for many years (Plant Conservation Alliance 1997). As such, it ranked relatively high in terms of its tendency to become a management problem. Field garlic and Johnson grass both received a high rank for tendency to become a management problem as well. All three of these species are difficult to control because they are so widespread; however, Chinese lespedeza is much more prevalent across the Research Park than either field garlic or Johnson grass.

Chinese yam received an overall rank of seven and had a relatively high rank for impact because it is a climbing vine that spreads rapidly. It can reproduce both vegetatively and through aerial bulbils, which is another reason for its high rank in impact. However, Chinese yam received a low rank for control because it occurs in relatively few locations on the Research Park. Chinese yam was mostly found along roadsides and the edges of management areas. In these areas it often forms large clumps and completely covers native vegetation.

Rankings for tree-of heaven (8") and empress tre (12") were affected by their tendency to become a management problem because their seeds are capable of widespread dispersal. Both 
tree-of-heaven and empress tree were found growing only along roadsides; however, tree-ofheaven usually occurs in clumps, while empress tree often occurs as an individual.

Although bull thistle (17") produces abundant seed that is readily dispersed by wind, it ranked low in impact because its seeds are not capable of widespread dispersal. Bull thistle occurs in minimal numbers along roadsides and fields and is not a threat to management areas. Spearmint $\left(15^{\text {th }}\right)$, on the other hand, ranked high in impact because it occurs throughout Hembree Marsh Natural Area. Although it should not be considered a management concern on the Research Park as a whole, it is important in Hembree Marsh because of its abundance therein.

Autumn olive ranked tenth and is mostly a problem along roadsides. Although it was found in minimal numbers within management areas, it is generally requires disturbance and ample sunlight for establishment and growth. Similar to autumn olive, crown vetch (18") also occurs in areas with high solar insolation. Crown vetch was found in only one location on the Research Park and should not be considered a management problem. It was included in the ranking simply because the population was observed and was thought to have the potential to become a problem in the future.

Oriental bittersweet (11") and periwinkle (14") both received their highest score in impact because they are both vines and are capable of overtopping and thereby excluding native vegetation. Oriental bittersweet received a low score for control because it was found in only one location on the Research Park and removal has been initiated from that location. In contrast, periwinkle was found in several locations and was observed to form dense mats in the understory of second-growth forest stands.

Finally, watercress (16") ranked low for control because the populations observed were small and could be easily removed by hand. It was only found in areas where running water and ample sunlight were available. Watercress should not be considered a management concern because it has a low impact in native communities and can easily be controlled.

\subsection{SPECIES RANKS FOR EACH MANAGEMENT AREA}

The relative rank of invasive plant species present within each management area tended to mirror the ranking for the Research Park as whole. For example, the most problematic plant for the Research Park as a whole - microstegium - was ranked first in each of the 12 management areas in which it was present. The four management areas in which microstegium was not present included two power transmission rights-of-way (Natural Areas 8 and 43), a marsh dominated by emergent vegetation (Natural Area 24), and a cedar barren (Reference Area 8). Although microstegium could conceivably become established in each of these management areas, they do not represent habitats typically invaded by this plant (Barden 1987, Redman 1995).

Japanese honeysuckle was present in 12 of the 16 management areas surveyed. Similar to microstegium, it was ranked second in each of these management areas, as it was for the Research Park as a whole. It was particularly abundant in Natural Area 9, where large clumps of vines reminiscent of kudzu hung from trees. In other Natural Areas, it was mostly present along fence rows and roadsides.

Chinese privet was present in 8 of the 16 management areas surveyed. It ranked second in 6 of those 8 management areas, even though it ranked third on the Research Park as a whole. The 
management areas in which Chinese privet was found were all areas where privet was expected to be found because of their close proximity to streams or roadsides.

Chinese lespedeza ranked number one in Reference Area 8 (Racoon Creek Cedar Barren) whereas it ranked sixth on the Research Park as a whole. In contrast with adjacent stands of closed-canopy deciduous forest on more mesic sites, solar insolation at ground level within the cedar barren is relatively high. These high levels of sunlight tend to favor the establishmentand growth of lespedeza. In all other management areas where it was present, lespedeza was ranked relatively low.

Natural Area 24, or Hembree Marsh, contains a large, dense population of spearmint that could potentially affect native wetland plants. No other invasive species examined as part of this survey were found within Hembree Marsh, probably because the perennially high water tables preclude the establishment of species less tolerant of periodic or permanent inundation. Thus, spearmint ranked first in this Natural Area. 



\section{CONCLUSIONS}

\subsection{RANKING NONNATIVE, INVASIVE PLANTS ON THE RESEARCH PARK}

The National Environmental Research Park and its component management areas contain a total of 167 nonnative invasive plants that may have potential negative effects on native plant and animal communities. These invasive plants are not unique to the Research Park; indeed, they are present throughout the entire southern Appalachian region of the United States. Of the $\mathbf{1 8}$ species surveyed in this study, microstegium, Japanese honeysuckle, Chinese privet, kudzu, and multiflora rose are among the most problematic invasive plants on the Research Park and its component management areas. These species are abundant throughout the southern Appalachian region and have all been ranked as particular management problems in other qualitative and semiquantitativerankings of nonnative, invasive plants in the region (TennesseeExotic Pest Plant Council 1996, Kuppinger 2000). However, results of this research can be used to prioritize management and research activities related to these invasive taxa on the Research Park as a whole and for specific Natural or Reference Areas.

Overall, the U.S. Geological Survey ranking system was relatively straightforward and contained the componentsthought to provide an adequate assessment of the impact of invasive plants: abundance, impact per individual, and total area occupied (Parker et al. 1999). However, the ranking system does have some flaws. For example, in all but one case, it allows only one answer to be chosen for each question. In particular, this was a problem for the question "Distribution relative to disturbance regime," in which the options early, mid-, or late successional sites could be chosen. For plants such as microstegium and Japanese honeysuckle, more than one answer would have been appropriate. We dealt with this specific problem by selecting the option that portrayed the latest successional stage in which a particular species could be found.

\subsection{THE NEED FOR ADDITIONAL RESEARCH}

As we gathered information from the literature about the traits and characteristics of individual species, it became apparent that basic autecological information on many invasive species is not readily available. This was particularly true for the less-abundant and least-problematic taxa, but even basic quantitive information on the more common taxa was sometimes lacking. In particular, data on species competitive ability, the number of seeds produced per plant, the viability and longevity of the seedbank, and the difficulty of control were often difficult to procure. Additional information on these topics would improve our ability to rank these species.

In addition, quantitative data on the effects of these species on the invaded plant and animal communities and ecosystems were seldom available. This is not a new problem in the field of invasion biology or plant ecology, nor is it specific to the particular species in question, the Research Park, or the region. In fact, scientists seldom collect basic data directed at quantification of effects of plant invasions on native ecological systems, and most of the discussion of ecological effects of invaders is anecdotal (Parker et al. 1999). In fact, Parker et al. (1999), in a recent review of scientific assessments of ecological impacts of invasions, stated that "Despite the considerable attention invasive species receive, our lamentable paucity of data on impacts leaves us largely ignorant about the ecologicalchanges they have brought about." Obviously, additional research focused on the general effects of individual invasive species on individuals, populations, communities, and ecosystems is much needed. 
In addition, there is a great need and potential to learn more about invasive plants in the various management areas on the Research Park, in the Ridge and Valley Province, and in the southern Appalachian region as a whole. Future research should focus on individual plant characteristics and the effects of invasive plants on native communities; research priorities could be guided by the results of the ranking conducted herein. For example, an ongoing study of microstegiumis focused on constraints to its distribution and abundance, and its response to interacting environmental variables (Patrice Cole, University of Tennessee, July 2001, personal communication). In addition, an ongoing study of the effects of elevated atmospheric concentrations of $\mathrm{CO}_{2}$ on entire plant communities dominated by invasive plants (including microstegium and Japanese honeysuckle) will shed light on potential interactions between plant invasions and global change (Belote, Travis, University of Tennessee, 2001, personal communication).

Similarly, studies of the effects of disturbance (e.g., logging, roads, and construction and maintenance of power line rights-of-way) could yield important information on the ways in which invasive plants establish and spread. Research on different control methods could aid in implementing management strategies for eradication of invasive plants. In all, additional research will yield information necessary to further prioritize management activities related to different invasive plant species. Finally, this ranking system could be used to similarly rank the many other nonnative, invasive species present on the Research Park that we did not include in this study.

\section{DEVELOPMENT OF MANAGEMENT STRATEGIES FOR THE RESEARCH PARK}

Results of this study and other research can be used to develop a management strategy for the most problematic invasive species on the Research Park and its component management areas. Strategies for management could take one or both of two non-mutually excusive approaches. First, management priorities could be site-specific(i.e., focused on particular management areas most threatened by a suite of invasive species). For example, sites that include large populations or many species of invasive plants, or sites with species of special concern, may be targets for particular management activities. Second, management priorities could be species-specific focusing on a particular invasive (or native) plant of special concern - across a variety of sites. Management activities should also probably be focused on invasive plant populations that are feasible to control. For example, eradication of microstegium from an area as extensive as the Research Park may represent a Sisyphean task.' However, intensive monitoring and control efforts may prevent the establishment and spread of other nonnative species before they become ecological or management problems.

\footnotetext{
${ }^{1}$ Sisyphus, a legendary king of Corinth, was condemned to roll a heavy rock up a hill in faces and have it roll down again as it approached the top.
} 


\section{REFERENCES}

APRS Implementation Team. 2000. Alien Plants Ranking System. Version 5.1. Jamestown, N.D. Accessed on-line from the Northern Prairie Wildlife Research Center (Version Feb. 17, 2000) [http://www.npwrc.usgs.gov/resource/2000/aprs/aprs.htm].

Awl, J., L. Pounds, B. A. Rosensteel, A. L. King, and P. A. Hamlett. 1996. Survey of Protected Vascular Plants on the Oak Ridge Reservation. ES/ER/TM-194, Oak Ridge National Laboratory, Oak Ridge, Tennessee.

Barden, L. S. 1987. Invasion of Microstegiurn virnineurn (Poaceae), an exotic, annual, shadetolerant, $\mathrm{C}_{4}$ grass, into a North Carolina floodplain. Am. Midland Nat. 118:40-45.

Daubenmire, R. 1978. Plant Geography: With Special Reference to North America. Academic Press, New York.

Cunningham, M., L. Pounds, S. Oberholsler, P. Parr, L. Edwards, B. Rosensteel, and L. Mann. 1993. Resource Management Plan for the Oak Ridge Reservation. Volume 29: Rare Plants on the Oak Ridge Reservation. ORNL/NERP-7.

Hanson, P. J., D. E. Todd, M. A. Huston, J. D. Joslin, J. Croker, and R. M. Augé. 1998. Description and field performance of the Walker Branch Throughfall DisplacementExperiment: 1993-1996. ORNL/TM-13586. Oak Ridge National Laboratory.

Hiebert, R. D. and J. Stubbendieck. 1993. Handbook for Ranking Exotic Plants for Management and Control. Natural Resources Report NPS/NRMWRO/NRR-93/08. U.S. Department of the Interior, National Park Service. Natural Resources Publication Office, Denver.

Johnson, D. W. and R. I. Van Hook (eds.). 1989. Analysis of Biogeochemical Cycling Processes in Walker Branch Watershed. Springer-Verlag. New York. 401 p.

Kuppinger, D. 2000. Management of plant invasions in the Southern Appalachians. Chinquapin 8:21.

Lonsdale, W. M. 1999. Global patterns of plant invasions and the concept of invasibility. Ecology 80:1522-1536.

McKnight, T. L. 1997. Regional Geography of the United States and Canada. Prentice Hall, Inc., Uppe-K. Saddle River, N.J.

National Park Service. 1999. Non-native, invasive plants in the Great Smoky Mountains National Park (unpublished manuscript).

Oak Ridge National Laboratory. August 2002. Oak Ridge National Laboratory Land and Facilities Plan. ORNL/TM-2002/1. Available on-line [http://www.ornl.gov/ dmsi/landUse/]. Accessed October 16,2002.

Parker, I. M., D. Simberloff, W. M. Lonsdale, K. Goodell, M. Wonham, P. M. Kareiva, M. H. Williamson, B. Van Holle, P. B. Moyle, J. E. Byers, and L. Goldwasser. 1999. Impact: Toward a framework for understanding the ecological effects of invaders. Biol. Inv. 1:3-19. 
Plant Conservation Alliance, Alien Plant Working Group. 1997. Kudzu. Factsheet. Available on-line [http://www.nps.gov/plants/alien/fact/pulol.htm]. Accessed Mar. 9, 2001.

Pounds, L. R., P. D. Parr, and M. G. Ryon. 1993. Resource Management Plan for the Cak Ridge Reservation. Volume 30: Oak Ridge National Environmental Research Park Natural Areas and Reference Areas - Oak Ridge Reservation Environmentally Sensitive Sites Containing Special Plants, Animals, and Communities. ORNL/NERP-8.

Redman, D. E. 1995. Distribution and habitat types for Nepal Microstegium [Microstegium vimineum (Trin.) Camus] in Maryland and the District of Columbia. Castenea 60:270-275.

Rejmanek, M., and D. Richardson. 1996. What attributes make some plant species more invasive? Ecology 77:1655-1661.

Research Committee of the Tennessee Exotic Pest Plant Council. 1996. Invasive Exotic Pest Plants in Tennessee. Available on-line through the SoutheastExotic Pest Plant Council [http://www.seeppc.org]. Accessed May 17,2002.

Sallabanks, R. 1993. Fruiting plant attractiveness to avian seed dispersers: Native vs. invasive Crataegus in western Oregon. Madrono 40:108-116.

SoutheastExotic Pest Plant Council (SEPPC). 1996. "Tennessee Exotic Pest Plant Management Manual.” Available on-line [http://www.seeppc.org/stateddoc.cfm?id=469]. Accessed May 17, 2002.

USDA, NRCS. 2001. The PLANTS Database, Version 3.1 (http://plants.usda.gov). National Plant Center, Baton Rouge, LA 70874-4490. Accessed May 17,2001.

Vitousek, P. M. 1990. Biological invasions and ecosystem processes: Towards an integration of population biology and ecosystem studies. Oikos 57:7-13.

White, P. S. 1997. Biodiversity and the exotic species threat. Exotic Pests of Eastern Forests. USDA Forest Service and Tennessee Exotic Pest Plant Council. Nashville. Apr. 8-10, 1997.

Wofford, B. E., and R. Kral. 1993. Checklist of the vascular plants of Tennessee. Sida, Botanical Miscellany 10:1-66. 


\section{APPENDIX A}

NONNATIVE PLANT SPECIES ON THE RESEARCH PARK 

Table A.l. Nonnative plant species on the Research Park (Awl et al. 1996)

\begin{tabular}{|c|c|}
\hline Scientific name & Common name \\
\hline Abutilon theophrasti & Velvet leaf \\
\hline Agrostemma githago & Corncockle \\
\hline Agrostis stolonifera & Creeping bentgrass \\
\hline Ailanthus altissima & Tree-of-heaven \\
\hline Albiziajulibrissin & Mimosa \\
\hline Allium ampeloprasum & Garlic \\
\hline Allium vineale & Field garlic \\
\hline Amaranthus hybridus & Amaranth \\
\hline Amaranthus spinosus & Spiny amaranth \\
\hline Anagallis arvensis & Pimpernel \\
\hline Anthoxanthumodoratum & Sweet vernal grass \\
\hline Arabidopsis thaliana & Mouse-ear cress \\
\hline Arctinium minus & Burdock \\
\hline Arenaria serpyllifolia & Thyme-leaf sandwort \\
\hline Arthraxon hispidus & Jointed grass \\
\hline Asparagus officinalis & Asparagus \\
\hline Barbarea verna & Early winter-cress \\
\hline Barbarea vulgaris & Yellow rocket \\
\hline Belamcanda chinensis & Blackberry lily \\
\hline Berberis thunbergii & Japanese barberry \\
\hline Brassica rapa & Rape mustard \\
\hline Bromus commutatus & Common brome grass \\
\hline Bromus hordeaceus & Soft chess \\
\hline Bromusjaponicus & Japanese chess \\
\hline Bromus tectorum & Brome grass \\
\hline Buglossoides arvense & --- \\
\hline Buxus sempervirens & Boxwood \\
\hline Calamintha nepeta & Basil-thyme \\
\hline Capsella bursa-pastons & Sheperd' s purse \\
\hline Cardamine hirsute & Hairy bittercress \\
\hline Cardamine parviflora & --- \\
\hline Catalpa binonioides & Catalpa \\
\hline Celastrusorbiculatus & Oriental bittersweet \\
\hline Centaurea cyanus & Bachelor's button \\
\hline Centaurea maculosa & Bachelor's button \\
\hline Cerastiumfontanum & Mouse-ear chickweed \\
\hline Cerastiumglomeratum & Mouse-ear chickweed \\
\hline Chaennorrhinumminus & Lesser toadflax \\
\hline Chenopodium album & White goosefoot \\
\hline Chenopodium ambrosioides & Fragrant goosefoot \\
\hline Chrysanthemum leucanthemum & Daisy \\
\hline Cichorium intybus & chicory \\
\hline Cirsium arvense & Canada thistle \\
\hline Cirsium vulgare & Bull thistle \\
\hline
\end{tabular}


Table A.I (continued)

\begin{tabular}{|c|c|}
\hline Scientific name & Common name \\
\hline Commelina communis & Common dayflower \\
\hline Consolida ambigua & Rocket larkspur \\
\hline Convallariamajalis & Lily-of-the-valley \\
\hline Coronillavaria & Crown vetch \\
\hline Crepispulchra & Hawk's beard \\
\hline Cynodon dactylon & Bermuda grass \\
\hline Dactylis glomerata & Orchard grass \\
\hline Datura stramonium & Jimson weed \\
\hline Daucus carota & Queen Anne's lace \\
\hline Dianthus armera & Deptford pink \\
\hline Digitaria ischaemum & Smooth crabgrass \\
\hline Digitaria sanguinalis & Crabgrass \\
\hline Dioscorea batatas & Chinese yam \\
\hline Dipsacus fullonum & Teasel \\
\hline Draba verna & Whitlow grass \\
\hline Duchesnea indica & Barren strawberry \\
\hline Echinochloa crusgalli & Bamyard grass \\
\hline Elaeagnus pungens & Thorny autumn olive \\
\hline Elaeagnus umbellate & Autumn olive \\
\hline Eleusine indica & Goosegrass \\
\hline Eragrostis cilianensis & Lovegrass \\
\hline Eragrostis curvula & South African lovegrass \\
\hline Erysimum cheiranthoides & Worm-seed mustard \\
\hline Festuca arundinacea & Meadow fescue \\
\hline Festuca pratensis & Fescue \\
\hline Festuca rubra & Red fescue \\
\hline Galium parisiense & --- \\
\hline Galium pedamontanum & Narrow bedstraw \\
\hline Geranium columbinum & Longstalk crane’s-bill \\
\hline Glechoma hederacea & Ground-ivy, Gill-over-the-ground \\
\hline Hedera helix & English ivy \\
\hline Hemerocallis fulva & Day-lily \\
\hline Hibiscus trionum & Flower of an hour \\
\hline Holcus lanatus & Velvet grass \\
\hline Holosteum umbellatum & Jagged chickweed \\
\hline Hypericum perforatum & Common St. John's-wort \\
\hline Ipomoea coccinea & Scarlet morning-glory \\
\hline Ipomoea hederacea & Ivy-leaved morning-glory \\
\hline Ipomoea purpurea & Purple morning-glory \\
\hline Iris germanica & German iris \\
\hline Iris pseudocorus & Yellow European ins \\
\hline Kummerowia stipulacea & Korean bush-clover \\
\hline Kummerowia striata & Japanese clover \\
\hline
\end{tabular}


Table A.I (continued)

\begin{tabular}{|c|c|}
\hline Scientific name & Common name \\
\hline Lactuca saligna & Willow-leaved lettuce \\
\hline Lactuca serriola & Prickly lettuce \\
\hline Lamium amplexicaule & Henbit \\
\hline Lamium purpureum & Purple dead-nettle \\
\hline Lathyrus latifolia & Everlasting pea \\
\hline Leonurus cardiaca & Motherwort \\
\hline Lepidium campestre & Cow-cress \\
\hline Lespedeza bicolor & Shrubby bush-clover \\
\hline Lespedeza cuneata & Chinese lespedeza \\
\hline Ligustrum sinense & Chinese privet \\
\hline Ligustrum vulgare & Privet \\
\hline Linaria vulgaris & Butter-and-eggs \\
\hline Lolium multiflorum & Italian ryegrass \\
\hline Loliumperenne & Perennial ryegrass \\
\hline Lonicerajaponica & Japanese honeysuckle \\
\hline Lonicera maackii & Bush honeysuckle \\
\hline Lotus comiculatus & Birdfoot trefoil \\
\hline Lysimachia nummularia & Moneywort \\
\hline Lythrum salicaria & Purple loosestrife \\
\hline Maclura pomifera & Osage-orange \\
\hline Mahonia bealei & Oregon grape \\
\hline Malus pumila & Apple \\
\hline Medicago lupulina & Black medick \\
\hline Medicago sativa & Alfalfa \\
\hline Melilotus alba & White sweet-clover \\
\hline Melilotus officinalis & Yellow sweet-clover \\
\hline Mentha spicata & Spearmint \\
\hline Mentha $\mathbf{x}$ piperita & Peppermint \\
\hline Microstegium vimineum & Microstegium (Japanese grass) \\
\hline Mollugo verticillata & Carpet-weed \\
\hline Mosla dianthera & -- \\
\hline Murdannia keisak & --- \\
\hline Myriophyllum spicata & Eurasian water-milfoil \\
\hline Narcissuspseudonarcissus & Daffodil \\
\hline Nasturtium officinale & Watercress \\
\hline Nicandra physalodes & Apple-of-Peru \\
\hline Omithogalum umellatum & Star of Bethlehem \\
\hline Paspalum dilatatum & --- \\
\hline Paulownia tomentosa & Empress tree \\
\hline Perilla frutescens & Beefsteak plant \\
\hline Phleumpratense & Common timothy \\
\hline Plantago lanceolata & Plantain \\
\hline Poa апnua & Annual bluegrass \\
\hline Poa compressa & Bluegrass \\
\hline
\end{tabular}


Table A.l (continued)

\begin{tabular}{|c|c|}
\hline Scientific name & Common name \\
\hline Poapratensis & Kentucky bluegrass \\
\hline Polygonum cespitosum & Smartweed \\
\hline Polygonum cuspidatum & Japanese knotweed \\
\hline Polygonum hydropiper & Water-pepper \\
\hline Polygonum persicaria & Smartweed \\
\hline Poncircus trifoliata & Trifoliate orange \\
\hline Populus alba & Silvery poplar \\
\hline Populus xjackii & -- \\
\hline Potamogeton crispus & Curly pondweed \\
\hline Potentilla recta & Rough-fruited cinquefoil \\
\hline Prunella vulgaris & Heal-all \\
\hline Pueraria montana & Kudzu \\
\hline Ranunculus acris & Common buttercup \\
\hline Ranunculus bulbosus & Bulbous buttercup \\
\hline Ranunculus parviflorus & Small-floweredbuttercup \\
\hline Ranunculus repens & Creeping buttercup \\
\hline Ranunculus sardos & -- \\
\hline Rosa multiflora & Multiflorarose \\
\hline Rubus phoenicolasius & Wineberry \\
\hline Rumex acetosella & Shep sorrel \\
\hline Rumex conglomeratus & Clustered dock \\
\hline Rumex crispus & Curled dock \\
\hline Rumex obtusifolius & Bitter dock \\
\hline Salix alba & White willow \\
\hline Salix babylonica & Weeping willow \\
\hline Saponaria officinalis & Soapwort \\
\hline Secale cereale & Rye \\
\hline Senna obtusifolia & Sickle-pod \\
\hline Setariafaberi & Foxtail \\
\hline Setaria pumila & Foxtail \\
\hline Setaria viridis & Green foxtail \\
\hline Sherardia arvensis & Field-madder \\
\hline Sida spinosa & Prickly mallow \\
\hline Sonchus asper & Prickly sow-thistle \\
\hline Sorghum bicolor & Milo \\
\hline Sorghum Mepense & Johnsongrass \\
\hline Spiraea douglasii & Spiraea \\
\hline Spirodela punctata & Duckweed \\
\hline Sporobolus indicus & Smutgrass \\
\hline Stellaria media & Common chickweed \\
\hline Taraxacum oficinale & Common dandelion \\
\hline Thlaspi perfoliatum & Thoroughwort penny-cress \\
\hline Tragopogon dubius & --- \\
\hline Trifolium campestre & Low hop-clover \\
\hline
\end{tabular}


Table A.l (continued)

\begin{tabular}{ll}
\hline Scientific name & Common name \\
\hline Trifolium hybridum & Alsike clover \\
Trifoliumpratense & Red clover \\
Trifolium repens & White clover \\
Triticum x aestivum & Wheat \\
Tussilagofarfara & Coltsfoot \\
Urtica dioica & Stinging nettle \\
Valerianella locusta & European corn salad \\
Verbascumblattaria & Moth mullein \\
Verbascumthaspus & Mullein \\
Veronicaagrestis & Field speedwell \\
Veronica arvensis & Corn speedwell \\
Veronicahederaefolia & Ivy-leaved speedwell \\
Veronicaofficinalis & Common speedwell \\
Veronica serpyllifolia & Thyme-leaved speedwell \\
Vicia augustifolia & Narrow-leaved vetch \\
Vicia villosa & Hairy vetch \\
Vincaminor & Common periwinkle \\
Vitaagnus-castus & --- \\
Vulpia myuros & Rat-tail fescue \\
\hline
\end{tabular}


APPENDIX B

AGGRESSIVE INVASIVE PLANT SPECIES ON THE RESEARCH PARK 
B-2 
Table B.l. Aggressive invasive plant species on the Research Park

(Awl et al. 1996)

\begin{tabular}{|c|c|}
\hline Scientific name & Common name \\
\hline Ailanthus altissima & Tree-of-heaven \\
\hline Allium vineale & Field garlic \\
\hline Amaranthus hybridus & Green amaranthus \\
\hline Arthraxon hispidus & Jointed grass \\
\hline Celastrus orbiculatus & Oriental bittersweet \\
\hline Cirsiumvulgare & Bull thistle \\
\hline Coronillavaria & Crown vetch \\
\hline Dioscorea batatas & Chinese yam \\
\hline Echinochloa-crusgalli & Barnyard grass \\
\hline Elaeagnuspungens & Thorny autumn olive \\
\hline Elaeagnus umbellata & Autumn olive \\
\hline Glechomahederacea & Gill-over-the-ground, ground ivy \\
\hline Kummerowia stipulacea & Korean bush clover \\
\hline Kummerowia striata & Japanese clover \\
\hline Kyllinga brevifoliodes & --- \\
\hline Lespedeza bicolor & Shrubby bush clover \\
\hline Lespedeza cuneata & Chinese lespedeza \\
\hline Ligustrum sinense & Chinese privet \\
\hline Lonicerajaponica & Japanese honeysuckle \\
\hline Lysimachia nummularia & Moneywort \\
\hline Lythrum salicaria & Purple loosestrife \\
\hline Mahonia bealei & Oregon grape \\
\hline Mentha spicata & Spearmint \\
\hline Mentha $\mathbf{x}$ piperita & Peppermint \\
\hline Microstegium vimineum & Microstegium (Japanese grass) \\
\hline Myriophyllum spicata & Eurasian water-milfoil \\
\hline Nasturtium oflcinale & Watercress \\
\hline Paulownia tomentosa & Empress tree \\
\hline Plantago lanceolata & Common plantain \\
\hline Poapratensis & Kentucky bluegrass \\
\hline Polygonum cuspidatum & Japanese knotweed \\
\hline Polygonumpersicaria & Smartweed \\
\hline Potamogeton crispus & Curly pondweed \\
\hline Pueraria montana & Kudzu \\
\hline Rosa multiflora & Multiflora rose \\
\hline Rumex conglomeratus & Clustered dock \\
\hline Sorghum halepense & Johnsongrass \\
\hline Urtica dioica & Stinging nettle \\
\hline Veronicaarvensis & Corn speedwell \\
\hline Veronicaofficinalis & Common speedwell \\
\hline Veronicaserpyllifolia & Thyme-leaved speedwell \\
\hline Vicia villosa & Hairy vetch \\
\hline Vincaminor & Common periwinkle \\
\hline
\end{tabular}


.

. 
APPENDIX C

ALIEN PLANTS RANKING SYSTEM, VERSION 5.1 


\section{Alien Plants Ranking System, Version 5.1 \\ (APRS Implementation Team 2000)}

\section{Significance of threat or impact (site characteristics)}

1. Distribution relative to disturbance regime

a. Found only within sites disturbed within the last 3 years or sites regularly disturbed

b. Found in sites disturbed within the last 10years

c. Found in mid-successional sites disturbed 11 to 50 years before present

d. Found in late-successionalsites disturbed 51 to 100 years before present

e. Found in highquality natural areas with no known major disturbance for 100 years

f. Unknown

2. Areal extent of populations
a. Not in site, but in adjacent areas
b. Found in less than $5 \%$ of site
c. Found in between $5 \%$ and $10 \%$ of site
d. Found in between $10 \%$ and $25 \%$ of site
e. Found in more than $\mathbf{2 5} \%$ of site
f. Unknown

3. Numerical dominance of species within a community
a. Not found on site
b. Usually observed as a single individual (or fewer than 5 per $5 \mathrm{~m}^{2}$ )
c. Usually observed in numbers less than the 2 or 3 most common native species in the community (but more than 5 per $5 \mathrm{~m}^{2}$ )
d. Usually observed in numbers approximately equivalent to the most common native species in the community
e. Usually observed in numbers greater than the most common native species in the community
f. Unknown

4. Association with native community
a. Associated with weedy (early successional) species
b. Associated with mid-successional species
c. Associated with dominant (late-successional) species
d. Displaces native plant community
e. Unknown

5. Hybridization with native species
a. Not known to hybridize with native species
b. Known to hybridize with native species
c. unknown 
6. Degree of threat and impact
a. Little or no increase in numbers of individuals and populations and no invasion of native communities
b. Present in native communities, but static or decreasing
c. Moderate rate of increase in numbers of individuals and populations; little or no invasion of native communities
d. Moderate rate of increase in numbers of individuals and populations; invading native plant communities
e. High rate of increase of numbers of individuals and populations; invading and replacing or highly modifying native plant communities
f. Unknown

7. Effects on management goals
a. No effect
b. Little impact on site management goals
c. Moderate impact on site management goals
d. Large impact on site management goals
e. Unknown

\section{Innate ability to become a pest}

8. Mode of reproduction
a. Rarely, if ever, reproduces in area
b. Reproduces almost entirely by vegetative means
c. Reproduces only by seed
d. Reproduces vegetatively and by seeds
e. Unknown

9. Vegetative reproduction
a. No vegetative reproduction
b. Vegetative reproduction rate maintains population
c. Vegetative reproduction rate results in moderate increase in population size
d. Vegetative reproduction rate results in rapid increase in population size
e. Unknown

10. Frequency of sexual reproduction for mature plant
a. Almost never reproduces sexually in area
b. Once every 5 or more years
c. Every other year
d. One or more times a year
e. Bursts of sexual reproduction in response to environmental stimulus
f. Unknown

11. Number of seeds per plant
a. Rarely, if ever, produces seed in area
b. Few $(0-10)$
c. Moderate $(11-1000)$
d. Many $(>1000)$
e. Unknown 
12. Dispersal ability
a. Little potential for long-distancedispersal
b. Great potential for long-distancedispersal
c. Unknown

13. Germinationrequirements
a. Requires open soil and disturbance to germinate
b. Can germinate in vegetated areas but in a narrow range or in special conditions
c. Can germinate in existing vegetation in a wide range of conditions
d. Unknown

14. Seedbanks
a. Seeds remain viable in the soil for less than 1 year
b. Seeds remain viable in the soil for 1 to 5 years
c. Seeds remain viable in the soil for more than 5 years
d. Unknown

15. Competitive ability
a. Poor competitor
b. Moderately successful competitor
c. Highly successful competitor
d. Unknown

16. Ecological effects (select all that apply)
a. Produces persistent litter or shade that affects germination or growth of native species
b. Produces allelochemicals
c. Affects availability of soil nutrients
d. Affects water availability to native plants
e. Changes natural fire regime
f. None of the above
g. Unknown

17. Known level of impact in natural areas
a. Not known to cause impacts in any other natural area
b. Known to cause impacts in natural areas, but with different habitats and climate zones
c. Known to cause low impact in natural areas with similar habitats and climate zones
d. Known to cause moderate impact in natural areas with similar habitats and climate zones
e. Known to cause high impact in natural areas with similar habitats and climate zones and/or on the list of most invasive alien plants for the region
f. unknown

\section{Difficulty of control}

18. Likelihood of successful control

a. This species has been eradicated in a natural area

b. Control (populationsdeclining) of this species has been achieved in a natural area 
c. Limited control (species is no longer spreading, but persists near precontrol levels) of this species has been achieved in a natural area

d. Control of this species has never been achieved in a natural area

e. Unknown

19. Saturation in surrounding region

a. Not present in areas surrounding the site

b. Present in few areas surrounding the site

c. Present in several areas but not entirely surrounding the site

d. Present in most areas surrounding the site

e. Unknown

20. Effectiveness of community management

a. Protection from disturbance effectively controls target species

b. Cultural techniques (burning, flooding) can be used to control target species

c. Restoration or preservation practices effectively control target species

d. The above options are not effective

e. Unknown

21. Vegetative regeneration

a. No resprouting following removal of aboveground growth

b. Sprouts from roots or stumps

c. Any plant part is a viable propagule

d. Unknown

22. Biological control
a. Biological control feasible
b. Potential may exist for biological control
c. Biological control not feasible (not practical, possible, or probable)
d. Unknown

23. Side effects of control measures
a. Control measures have little potential to affect native communities
b. Control measures are likely to cause moderate impacts on communities
c. Control measures are likely to cause major impacts on communities
d. Side effects of control unknown
e. Unknown 


\begin{abstract}
APPENDIX D
RESPONSES TO EACH RANKING SYSTEM QUESTION

(QUESTIONS 1 THROUGH 23) FOR EACH SPECIES

ON EACH MANAGEMENT AREA (MA) SURVEYED ON THE RESEARCH PARK
\end{abstract}

D-1 


$$
\text { D-2 }
$$


Table D1. Responses to Each Ranking System Question (Questions 1 through 23) for Each Species on Each Management Area (MA) Surveyed on the Research Park

\begin{tabular}{|c|c|c|c|c|c|c|c|c|c|c|c|c|c|c|c|c|c|c|c|c|c|c|c|c|}
\hline IA & Species" & 1 & & $\underline{3}$ & 4 & & 6 & 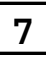 & - & 9 & 10 & 11 & 12 & 13 & 14 & 15 & 16 & 17 & 18 & 19 & 20 & 21 & 22 & \\
\hline \multirow[t]{7}{*}{2} & Mivi & $\bar{C}$ & $d$ & $d$ & $\mathrm{~b}$ & - & $\bar{e}$ & 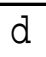 & & $B$ & $\mathrm{D}$ & C & $\mathrm{b}$ & $\mathrm{C}$ & $\mathrm{b}$ & $d$ & $a, d$ & $e$ & e & $d$ & C & $a$ & $d$ & \\
\hline & Lisi & $c$ & $c$ & h & $b$ & a & $d$ & $n$ & $d$ & D & D & d & $b$ & $c$ & $d$ & $d$ & $a, d$ & e & e & C & $\mathrm{b}$ & $\mathrm{b}$ & b & \\
\hline & Loja & $c$ & $d$ & $d$ & $b$ & a & b & & & B & D & 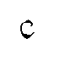 & $b$ & 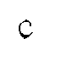 & $d$ & $d$ & $\mathbf{a}$ & e & e & & b & b & & \\
\hline & Lecu & a & a & a & a & 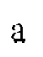 & $c$ & 0 & 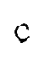 & $A$ & D & $e$ & 0 & $c$ & 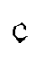 & $d$ & c & e & e & $d$ & $\mathrm{~b}$ & $d$ & $d$ & \\
\hline & Ceor & $c$ & a & a & $b$ & b & $c$ & & & $\mathrm{C}$ & F & $\mathrm{e}$ & & $d$ & & $d$ & $\mathbf{a}$ & e & b & b & $\mathrm{b}$ & $\mathrm{b}$ & $d$ & \\
\hline & Aial & a & a & 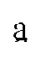 & a & 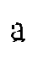 & c & & & $A$ & D & $d$ & & a & & $d$ & b & e & e & C & $\mathrm{b}$ & b & $d$ & \\
\hline & Elum & a & $b$ & $\xi$ & a & g & a & 8 & & $A$ & D & $\mathrm{e}$ & & $c$ & & $d$ & $a, c$ & e & e & b & $\mathrm{b}$ & b & $d$ & \\
\hline \multirow[t]{6}{*}{4} & Mivi & $c$ & $d$ & d & $b$ & & & & & $A$ & $d$ & $c$ & & $c$ & & $d$ & $a, d$ & e & e & $d$ & C & a & $d$ & \\
\hline & Lisi & $c$ & $c$ & 8 & $b$ & a & $d$ & 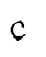 & & $D$ & $d$ & $d$ & & c & 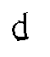 & $d$ & $a, d$ & e & e & C & $\mathrm{b}$ & $\mathrm{b}$ & $\mathrm{b}$ & \\
\hline & Lecu & a & $c$ & $d$ & a & a & $c$ & 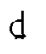 & & $A$ & $d$ & $d$ & 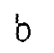 & $b$ & $\mathrm{C}$ & $d$ & $c$ & $e$ & e & $d$ & b & $d$ & $d$ & \\
\hline & Diba & C & C & $c$ & b & & e & d & & $D$ & & a & - & $d$ & & $d$ & a & e & e & C & C & $d$ & $d$ & \\
\hline & Pato & a & a & b & a & a & C & $\mathrm{b}$ & & C & 0 & $d$ & & $d$ & 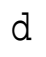 & $d$ & g & e & e & $\mathrm{b}$ & b & $\mathrm{b}$ & \pm & \\
\hline & Cova & a & a & $a$ & a & c & c & 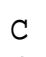 & & $\mathrm{C}$ & $\mathbf{f}$ & e & & $d$ & d & $d$ & $g$ & $d$ & e & d & a & d & $d$ & \\
\hline \multirow[t]{4}{*}{8} & Lесu & a & $c$ & $d$ & a & a & $d$ & $d$ & & $B$ & $d$ & $d$ & & $b$ & & $d$ & $c$ & d & e & $d$ & $e$ & $d$ & $d$ & \\
\hline & Loja & $c$ & $d$ & 0 & 6 & $a$ & $d$ & 0 & & $D$ & $d$ & $c$ & & $d$ & & $d$ & $a$ & e & e & $d$ & e & 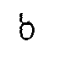 & $d$ & \\
\hline & Lisi & C & b & b & b & a & a & b & & $\mathrm{D}$ & $d$ & $d$ & $\mathrm{~b}$ & b & a & $c$ & $a, d$ & e & e & C & e & b & $d$ & \\
\hline & Pumo & a & a & e & a & a & $e$ & 0 & & $D$ & $a$ & a & & a & & $c$ & $\mathbf{a}$ & e & e & C & e & $d$ & $d$ & \\
\hline \multirow[t]{2}{*}{9} & Mivi & $c$ & e & 8 & 0 & a & & 0 & & 8 & & $c$ & & $c$ & & $c$ & $a, d$ & e & e & & e & a & $d$ & \\
\hline & Loja & $c$ & $d$ & 0 & 8 & $a$ & d & & & $D$ & & e & & $d$ & d & $d$ & $\mathbf{a}$ & e & e & o & e & b & $d$ & \\
\hline \multirow[t]{5}{*}{10} & Mivi & $c$ & e & $e$ & $b$ & a & 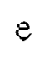 & g & d & 8 & $d$ & $c$ & 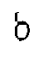 & $c$ & 8 & $c$ & $a, d$ & e & e & $d$ & e & $a$ & $d$ & \\
\hline & Diba & a & $c$ & c & a & a & e & 0 & 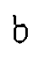 & $D$ & a & a & & $d$ & d & $\gamma$ & $\mathbf{a}$ & e & e & C & e & $d$ & d & \\
\hline & Pato & a & a & b & 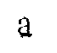 & 8 & & 8 & 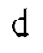 & C & 0 & $d$ & & $d$ & $d$ & $d$ & a & C & e & & e & ) & $d$ & \\
\hline & Lecu & a & $c$ & d & & 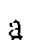 & d & 0 & & $A$ & 0 & $d$ & & $b$ & & $d$ & c & $d$ & e & & & $d$ & $d$ & \\
\hline & Loja & $c$ & $d$ & 0 & $b$ & $a$ & $d$ & 8 & & $D$ & & $c$ & & $d$ & & $d$ & $\mathbf{a}$ & e & e & $d$ & e & $\mathrm{b}$ & $d$ & \\
\hline \multirow[t]{4}{*}{11} & Romu & $c$ & $c$ & 0 & $b$ & 0 & d & 0 & $d$ & $D$ & 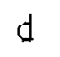 & e & 6 & $d$ & & $d$ & $\mathbf{a}$ & e & e & & e & $\mathrm{b}$ & $d$ & \\
\hline & Iivi & $c$ & $b$ & 0 & $b$ & 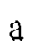 & & $d$ & & 8 & d & c & & $c$ & & $c$ & $a, d$ & e & e & $d$ & e & a & $d$ & \\
\hline & Lisi & $c$ & 8 & $b$ & b & 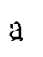 & & & d & $D$ & $d$ & $d$ & 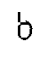 & $b$ & $d$ & $c$ & $a, d$ & e & e & C & e & $\mathrm{b}$ & $d$ & \\
\hline & Loja & c & d & 0 & $b$ & 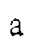 & & & & $D$ & & $c$ & & $d$ & & $d$ & $\mathbf{a}$ & e & & & e & b & $d$ & \\
\hline \multirow[t]{6}{*}{13} & Mivi & $c$ & a & e & o & a & $e$ & d & & $B$ & 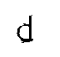 & d & & b & & $d$ & $a, d$ & e & e & & C & & $d$ & \\
\hline & Loja & $\mathrm{c}$ & $d$ & $c$ & $b$ & $a$ & $c$ & 6 & & 8 & $d$ & e & & $c$ & 9 & $d$ & $\mathbf{a}$ & e & e & $d$ & $b$ & b & $d$ & \\
\hline & Diba & $\mathrm{c}$ & $b$ & $b$ & 6 & $a$ & $e$ & $b$ & b & $C$ & & a & $b$ & $d$ & $d$ & $d$ & $\mathbf{a}$ & e & e & $\mathrm{b}$ & C & $d$ & $d$ & \\
\hline & Lecu & a & b & $\delta$ & a & a & & $\phi$ & & $A$ & & $d$ & & $b$ & & $d$ & c & e & e & & b & d & $d$ & \\
\hline & Elum & $c$ & 6 & $b$ & b & a & a & $b$ & & $A$ & $d$ & e & & $c$ & d & $d$ & $a, c$ & e & e & b & $\mathrm{b}$ & b & $d$ & \\
\hline & imi & $c$ & c & 0 & $b$ & a & & 8 & & $C$ & & a & & $d$ & & $d$ & $\mathbf{a}$ & $d$ & e & C & b & $d$ & b & \\
\hline \multirow[t]{6}{*}{18} & Mivi & $c$ & e & 8 & b & a & $e$ & d & d & $B$ & $d$ & $c$ & & $c$ & & $d$ & $a, d$ & e & e & o & C & & $d$ & \\
\hline & Lecu & a & $c$ & $d$ & a & a & d & 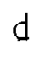 & & $A$ & $d$ & d & $b$ & $b$ & S & $d$ & c & e & e & $d$ & $\mathrm{~b}$ & d & $d$ & \\
\hline & Vimi & $c$ & $c$ & 0 & $b$ & $a$ & s & 8 & & $\mathrm{C}$ & 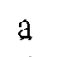 & a & & $d$ & & $d$ & $\mathbf{a}$ & $d$ & e & e & b & $d$ & b & \\
\hline & Loja & $c$ & d & $c$ & 6 & $a$ & e & 8 & d & B & $d$ & $c$ & 0 & $c$ & $\square$ & $d$ & $\mathbf{a}$ & e & e & $d$ & b & b & $d$ & \\
\hline & Pato & a & a & $b$ & a & $a$ & 0 & c & $d$ & $C$ & $d$ & $d$ & & $d$ & d & $d$ & g & e & e & $\mathrm{b}$ & $\mathrm{b}$ & b & $d$ & \\
\hline & Civu & a & 6 & $b$ & 8 & $a$ & 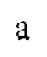 & b & & $A$ & 0 & $d$ & & $d$ & & $d$ & $g$ & $d$ & e & b & a & $d$ & $d$ & \\
\hline \multirow[t]{4}{*}{20} & Diba & a & $c$ & $c$ & a & a & e & d & b & $D$ & a & a & $v$ & $d$ & d & $d$ & $\mathbf{a}$ & e & e & C & C & $d$ & $d$ & \\
\hline & Lisi & $c$ & a & a & $b$ & a & d & (] & 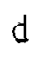 & $D$ & $d$ & $d$ & & c & & $d$ & $a, d$ & e & e & C & b & $\mathrm{b}$ & b & \\
\hline & Romu & a & $c$ & 0 & $a$ & 0 & d & $c$ & 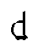 & $B$ & $d$ & e & 0 & $d$ & 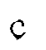 & $d$ & $\mathbf{a}$ & e & e & C & $\mathrm{b}$ & $\mathrm{b}$ & $d$ & \\
\hline & Lecu & a & a & d & $a$ & 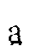 & 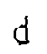 & $d$ & & $A$ & $d$ & $d$ & & $b$ & & $d$ & $\mathbf{a}$ & $\mathrm{e}$ & e & $d$ & $\mathrm{~b}$ & $d$ & $d$ & \\
\hline
\end{tabular}


Table D.I (Continued)

\begin{tabular}{|c|c|c|c|c|c|c|c|c|c|c|c|c|c|c|c|c|c|c|c|c|c|c|c|c|}
\hline MA & Species & 1 & 2 & 3 & 4 & 5 & 6 & 7 & 8 & 9 & 10 & & 12 & & & & 16 & & 18 & 19 & & & & 23 \\
\hline & Mivi & $\mathrm{C}$ & $\mathrm{C}$ & $\bar{d}$ & b & $\mathbf{a}$ & $\mathrm{d}$ & $\mathrm{d}$ & $\mathrm{d}$ & B & $\mathrm{d}$ & C & $\mathrm{b}$ & $\mathrm{C}$ & $\mathrm{b}$ & d & $a, d$ & e & e & d & C & $\mathbf{a}$ & d & C \\
\hline & Soha & $\mathbf{a}$ & $\mathbf{a}$ & $\mathbf{a}$ & $\mathbf{a}$ & a & $\mathrm{c}$ & b & & $E$ & $\mathrm{f}$ & e & $c$ & d & d & d & $g$ & d & e & C & c & d & d & \\
\hline & Civu & $\mathbf{a}$ & b & b & $\mathbf{a}$ & $\mathbf{a}$ & a & 6 & c & A & d & d & a & $d$ & a & d & $g$ & c & e & b & a & $\mathrm{d}$ & d & a \\
\hline & Aial & $\mathbf{a}$ & a & c & $\mathbf{a}$ & $\mathbf{a}$ & C & $c$ & d & C & d & d & $b$ & a & d & d & $a, b$ & 8 & e & C & b & & d & b \\
\hline & Vimi & c & c & c & b & a & c & c & $b$ & C & $\mathrm{a}$ & a & a & d & & d & $a$ & d & & & & & & \\
\hline & Pито & $\mathbf{a}$ & $\mathbf{a}$ & e & a & a & e & d & b & D & a & a & a & a & a & C & a & e & C & C & C & d & d & c \\
\hline \multirow[t]{5}{*}{$21 \mathrm{a}$} & Mivi & c & d & $d$ & b & a & e & d & d & B & d & c & b & c & b & d & $a, d$ & e & e & d & C & a & d & C \\
\hline & Lisi & c & d & d & b & a & d & d & d & D & $d$ & d & $b$ & $c$ & d & d & $\mathrm{a}, \mathrm{d}$ & e & e & & & & & \\
\hline & Elum & c & c & $\mathrm{c}$ & b & $\mathbf{a}$ & $\mathrm{C}$ & $c$ & e & $\varepsilon$ & $d$ & e & c & $b$ & d & d & $a, c$ & $\varepsilon$ & e & C & b & b & d & b \\
\hline & Rоти & c & $\mathrm{c}$ & $\mathrm{c}$ & b & c & $d$ & $c$ & d & C & $d$ & e & $b$ & c & C & d & a & e & e & C & b & b & d & b \\
\hline & Loja & $\mathrm{C}$ & $d$ & $\mathrm{C}$ & b & a & e & $c$ & d & D & d & $c$ & $b$ & $c$ & d & d & a & e & e & d & b & & d & C \\
\hline 24 & Mesp & c & b & $\mathrm{c}$ & b & b & a & b & d & $E$ & d & e & a & b & d & d & g & d & e & b & b & & $\mathrm{d}$ & b \\
\hline \multirow[t]{5}{*}{42} & Diba & c & c & c & b & $\mathbf{a}$ & e & d & b & D & a & a & $b$ & c & d & d & a & e & e & C & C & d & d & C \\
\hline & Mivi & $\mathrm{c}$ & d & d & b & $\mathbf{a}$ & e & d & d & B & d & C & b & C & b & d & $a, d$ & $\varepsilon$ & e & $d$ & C & a & d & C \\
\hline & Lecu & a & C & c & a & a & $d$ & d & C & A & $d$ & d & b & b & C & $\mathrm{d}$ & $\mathrm{C}$ & d & e & d & b & & d & \\
\hline & Loja & $\mathrm{c}$ & d & $\mathrm{c}$ & b & a & e & $c$ & d & B & $d$ & c & $b$ & c & d & d & a & e & e & d & b & b & d & C \\
\hline & Romu & c & c & c & b & c & $d$ & c & d & C & d & $\mathrm{e}$ & b & c & C & d & a & e & e & C & b & b & $d$ & b \\
\hline \multirow[t]{7}{*}{43} & Alvi & a & d & C & $\mathbf{a}$ & a & e & d & $d$ & B & d & c & a & a & a & d & g & d & e & C & C & $d$ & d & C \\
\hline & Lecu & a & d & $d$ & a & $\mathrm{C}$ & $d$ & d & C & A & $d$ & $d$ & b & b & C & d & C & d & e & d & b & d & d & C \\
\hline & Elum & $\mathrm{C}$ & $\mathbf{a}$ & $\mathbf{a}$ & b & $\mathbf{a}$ & $\mathrm{C}$ & $c$ & $\mathrm{e}$ & E & d & e & $c$ & $b$ & d & d & $a, c$ & $e$ & e & c & b & b & d & b \\
\hline & Rоти & C & C & c & b & C & $\mathrm{d}$ & $c$ & d & C & $d$ & $e$ & $b$ & $c$ & C & $\mathrm{d}$ & $a$ & e & e & C & b & & d & b \\
\hline & Lisi & c & b & b & b & a & $\mathrm{d}$ & $c$ & d & D & $d$ & d & $b$ & $c$ & d & $d$ & $a, d$ & e & e & $\mathrm{c}$ & b & b & b & c \\
\hline & Loja & c & a & $a$ & b & a & e & $c$ & d & B & d & $c$ & $b$ & c & d & $\mathrm{d}$ & $a$ & e & e & $d$ & b & b & d & C \\
\hline & Naof & a & b & b & e & a & c & 6 & e & $\mathrm{E}$ & $\mathrm{d}$ & e & a & $b$ & d & d & a & c & e & b & b & a & d & a \\
\hline \multirow[t]{11}{*}{47} & Lisi & C & d & d & b & $\mathbf{a}$ & $d$ & d & d & D & $d$ & $d$ & $b$ & $c$ & $d$ & d & $a, d$ & e & e & $\mathrm{C}$ & b & b & b & $\mathrm{c}$ \\
\hline & Naof & $\mathbf{a}$ & b & b & e & $\mathbf{a}$ & $\mathrm{C}$ & b & e & $\mathrm{E}$ & d & e & a & b & d & $d$ & $a$ & C & e & b & b & a & d & a \\
\hline & Mivi & b & C & e & b & $\mathbf{a}$ & e & d & $d$ & B & d & C & b & C & b & d & a,d & $e$ & e & d & C & a & d & C \\
\hline & Loja & $\mathrm{C}$ & $d$ & C & b & a & e & d & d & $C$ & $d$ & $c$ & $b$ & $c$ & $d$ & d & $a$ & e & e & $\mathrm{d}$ & b & & d & C \\
\hline & Elum & $\mathrm{c}$ & $\mathbf{a}$ & $\mathbf{a}$ & b & $\mathbf{a}$ & $\mathrm{C}$ & $c$ & e & $E$ & d & e & c & $b$ & $\mathrm{~d}$ & d & $a, c$ & e & $e$ & C & b & b & d & b \\
\hline & Diba & C & c & $\mathrm{C}$ & b & a & e & d & $b$ & D & a & a & b & $c$ & d & $\mathrm{d}$ & $a$ & e & e & C & C & d & d & C \\
\hline & Lecu & a & C & $d$ & a & a & d & $d$ & $\mathrm{C}$ & A & $d$ & $d$ & b & b & C & $d$ & $\mathrm{C}$ & $d$ & e & $d$ & b & $d$ & $d$ & C \\
\hline & Civu & $\mathbf{a}$ & b & b & $\mathbf{a}$ & a & $\mathbf{a}$ & 6 & $c$ & A & d & d & a & a & a & d & g & d & e & b & a & d & d & a \\
\hline & Rоти & c & c & c & b & $\mathrm{c}$ & $d$ & $c$ & d & D & $d$ & e & b & c & C & d & a & e & e & C & b & b & d & b \\
\hline & Vimi & C & C & $\mathrm{c}$ & b & $\mathbf{a}$ & $\mathrm{C}$ & $c$ & $b$ & C & a & a & a & $b$ & $\mathrm{~d}$ & d & a & d & e & b & b & d & b & b \\
\hline & Aial & $\mathbf{a}$ & $\mathbf{a}$ & C & $\mathbf{a}$ & $\mathbf{a}$ & $\mathrm{d}$ & $c$ & d & C & $d$ & $d$ & $b$ & a & $\mathrm{d}$ & d & $a, b$ & $e$ & e & $\mathrm{C}$ & b & b & $d$ & b \\
\hline \multirow[t]{4}{*}{ RA8 } & Lecu & a & C & $d$ & a & a & e & d & c & A & $d$ & $d$ & b & $\mathrm{b}$ & C & d & $\mathrm{C}$ & $d$ & e & d & b & d & d & C \\
\hline & Soha & a & a & a & a & a & c & $b$ & e & $E$ & $\mathrm{f}$ & e & $c$ & $d$ & $\mathrm{~d}$ & d & g & d & e & C & C & d & d & b \\
\hline & Alvi & $\mathbf{a}$ & C & C & & $\mathbf{a}$ & $d$ & $\mathcal{C}$ & d & I & a & & $b$ & & a & d & g & $d$ & e & C & C & d & $\mathrm{d}$ & C \\
\hline & Lisi & c & $\mathbf{a}$ & $\mathbf{a}$ & b & a & $\mathrm{C}$ & $c$ & d & D & $d$ & d & $b$ & $b$ & $d$ & d & a,d & $\mathrm{e}$ & $e$ & C & $\mathrm{b}$ & $\mathrm{b}$ & b & C \\
\hline
\end{tabular}


Table D.1 (Continued)

\begin{tabular}{cccccccccccccccccccccccccc}
\hline MA & Species" & 1 & 2 & 3 & 4 & 5 & 6 & 7 & 8 & 9 & 10 & 11 & 12 & 13 & 14 & 15 & 16 & 17 & 18 & 19 & 20 & 21 & 22 & 23 \\
\hline WBW & Mini & c & d & d & b & a & e & d & d & B & d & c & b & c & b & c & a d d & e & e & d & e & a & d & e \\
& Vimi & c & c & c & b & a & c & c & b & C & a & a & a & d & d & b & a & d & e & e & e & d & d & e \\
Lecu & a & b & c & a & a & d & d & c & A & d & d & b & d & c & d & c & d & e & d & e & d & d & e \\
& Loja & c & d & c & b & a & d & c & D & D & d & c & b & d & d & d & a & e & e & d & e & b & d & e \\
\hline
\end{tabular}

"Mivi = Microstegium vimineum; Diba = Dioscorea batatas; Lecu = Lespedeza cuneata; Alvi = Allium vineale; Elum $=$ Elaeagnus umbellata; Lisi $=$ Ligustrum sinense $;$ Naof $=$ Nasturtium officinale $;$ Loja $=$ Lonicera japonica; Pumo = Pueraria montana $;$ Vimi $=$ Vinca minor; Aial $=$ Ailanthus altissima Civu $=$ Cirsium vulgare Mesp $=$ Mentha spicata $;$ Soha $=$ Sorghum halepense , Ceor $=$ Celastrus orbiculatus; Romu $=$ Rosa multiflora; Pato = Paulownia tomentosa Cova $=$ Coronilla varia 


\title{
APPENDIX E
}

\author{
RESPONSES TO EACH RANKING SYSTEM QUESTION \\ (QUESTIONS 1 THROUGH 23) FOR EACH SPECIES SURVEYED \\ IN THE NATIONAL ENVIRONMENTAL RESEARCH PARK
}




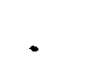




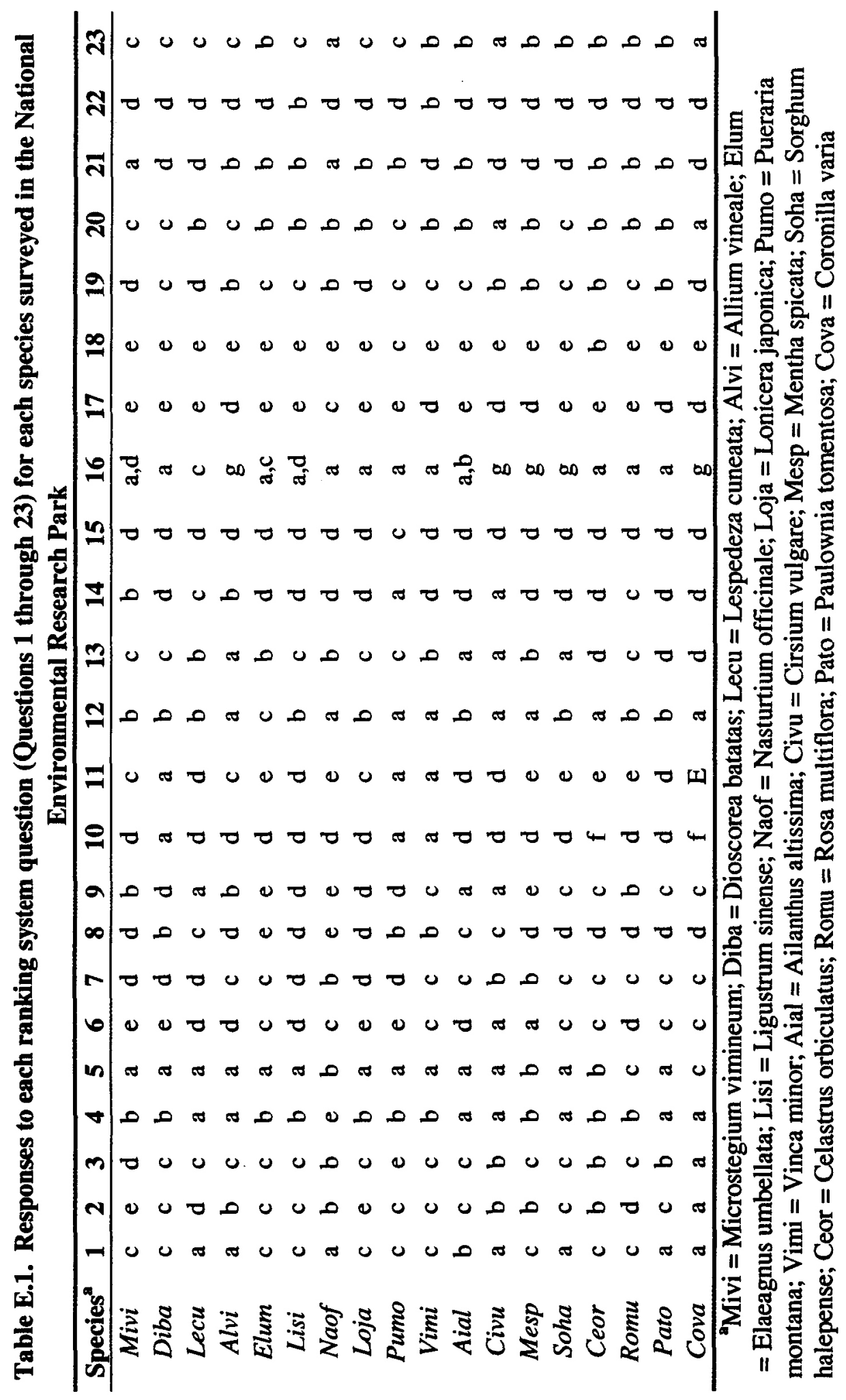


•

E-4 


\section{APPENDIX F}

SPECIES ABSTRACTS FOR EACH SPECIES SURVEYED IN THIS STUDY 
COMMON NAME:

SCIFNIIFIC NAME: DESCRIPTION:

HABITAT:

INTRODUCTION:

OCCURRENCE ON ORR:

CONTROL:
Tree-of-heaven

\section{Ailanthus altissima (Mill.) Swingle}

Tree-of-heaven is a small deciduous tree with smooth, gray bark. Leaves are compound and alternate with 15 to 27 lanceolate leaflets. These leaflets often have 1 to 5 rough teeth near their base. Flowers are green and occur in panicles near the ends of the branches (Radford et al. 1968). Seeds are contained within a pod called a samara. Samaras are shaped such that they can be twirled about and carried great distances by wind. Female trees can produce up to 350,000 seeds per year, while male trees produce a distinctive "burnt peanut" odor. Tree-of-heaven produces a toxin that accumulates in the soil and prevents other plants from establishing there (Virginia Native Plant Society 2000). Tree-of-heaven is considered a Rank 1 "Severe Threat" plant, which means that it "possesses characteristics of invasive species and spreads easily into native plant communities and displaces native vegetation" (TennesseeExotic Pest Plant Council 1990).

Tree-of-heaven can be found in a wide variety of disturbed habitats and is unusually tolerant of polluted environments (Conservation New England 1998) . It is mostly found along roadsides, fence rows, and vacant city lots (Virginia Native Plant Society 2000).

Tree-of-heaven is native to Asia and was first introduced to Europe in 1751. It was brought to the United States by a man from Philadelphia in 1784 (Conservation New England 1998).

Tree-of-heaven can be found along nearly all roadsides throughout the Oak Ridge Reservation.

Tree-of-heaven should be cut at ground level twice per year and a glyphosate herbicide applied to the stump. The herbicide should be applied late in the growing season so as to be translocated into the roots by the plant itself (Virginia Native Plant Society 2000).

\section{REFERENCES:}

Conservation New England. 1998. Available on-line

[http://omega.cc.umb.edu/ conne/jennjim/ailanthus.html]. Cited Aug. 23, 2000.

Radford, A. E., H. E. Ahles, and C. R. Bell. 1968. Manual of the Vascular Flora of the Carolinas. The University of North Carolina Press, Chapel Hill, N.C.

Tennessee Exotic Pest Plant Council. 1996. Available on-line [http://www.seeppc.org/doc.cfm?id=473]. Cited Mar. 9, 2001.

Virginia Native Plant Society. 2000. Available on-line

[http://www.vnps.org/invasive/invloni.htm]. Cited Aug. 232000. 
COMMON NAME:

SCIENTIFICNAME: DESCRIPTION:

HABITAT:

INTRODUCTION:

OCCURRENCEON ORR:

CONTROL:
Field garlic

\section{Allium vineale $\mathrm{L}$.}

Field garlic is a perennial that reproduces sexually with aerial seeds, asexually with aerial bulbils, and asexually with underground offsets, which are analogous to the garlic cloves that we eat (Ronsheim 1996). These offsets can remain dormant underground for 5 years (Ronsheim 1997) . Field garlic is considered a Rank 2 "Significant Threat" species, meaning that it may "possess some invasive characteristics, but have less impact on native plant communities; may have the capacity to invade natural communities along disturbance comdors, or to spread from stands in disturbed sites into undisturbed areas" (Tennessee Exotic Pest Plant Council 1990).

Field garlic grows in fields, roadsides, and can even grow in bottomland forests and pine woods (Ronsheim 1990). Field garlic was introduced to the United States from Central and Western Europe. It can now be found along the East coast from Georgia to Michigan (Ronsheim 1994). Field garlic is found in most power line cuts and along most sunny roadsides on the Oak Ridge Reservation. Control is difficult because field garlic possesses variable bulb dormancy. This trait allows field garlic to emerge over long periods of time (Leys and Slife 1988).

\section{REFERENCES:}

Leys, A. R., and F. W. Slife. 1988. Absorption and translocation of ${ }^{14} \mathrm{C}$-Chlorsulfuron and ${ }^{14} \mathrm{C}$ Metasulfuron in wild garlic (Allium vineale). Weed Sci. 36:1-4.

Ronsheim, M. L. 1994. Dispersal distances and predation rates of sexual and asexual propagules of Allium vineale L. Am. Midland Nat. 131:55-64.

Ronsheim, M. L. 1996.Evidence against a frequency-dependent advantage for sexual reproduction in Allium vineale. Am. Nat. 147:718-734.

Ronsheim, M. L. 1997. Distancedependent performance of asexual progeny in Allium vineale (Liliaceae). Am. J. Bot. 84:1279-1284.

Tennessee Exotic Pest Plant Council. 1996. Available on-line [http://www.seeppc.org/doc.cfm?id=473]. Cited Mar. 9,2001. 
COMMON NAME:

SCIENTIFICNAME:

DESCRIPTION:

HABITAT:

INTRODUCTION:

OCCURRENCEON ORR:

CONTROL:
Oriental bittersweet (Asian bittersweet)

Celastrus orbiculatus Thunb.

Oriental bittersweet is a deciduous, climbing vine with round to oblong leaves. Inflorescences have few flowers, which are small and green and occur in clusters. A capsule surrounding the seed turns orange when the seed ripens (PCA Alien Plant Working Group 2000). Oriental bittersweet is considered a Rank 2 "Significant Threat" species by the Tennessee Exotic Pest Plant Council (1996).

Oriental bittersweet grows in disturbed areas including roadsides and old homesites. It grows in alluvial woods and is capable of spreading into undisturbed mesic forests (PCA Alien Plant Working Group 2000).

Oriental bittersweet is native to Asia and was brought to the United States in the mid-1800s. It can be found as far north as Maine, south to Georgia, and west to Iowa (PCA Alien Plant Working Group 2000).

Oriental bittersweet has been found to occur in only one location on the Oak Ridge Reservation. Eradication procedures were carried out in July 2000.

Oriental bittersweet can be controlled through cutting and stump treatment with a glyphosate herbicide (PCA Alien Plant Working Group 2000).

\section{REFERENCES:}

PCA Alien Plant Working Group. 2000. Available on-line [http://www.mps.gov/plants/alien/fact/ceorhtm]. Cited Mar. 5,2001.

Tennessee Exotic Pest Plant Council. 1996. Available on-line [http://www.seeppc, org/doc,cfm?id=473], Cited Mar. 9,2001. 
COMMON NAME:

SCIENTIFICNAME:

DESCRIPTION:

HABITAT:

INTRODUCTION:

OCCURRENCE ON ORR:

CONTROL:
Bull thistle

Cirsiurn vulgare (Savi) Ten.

Bull thistle is a biennial plant that may produce up to $\mathbf{8 0 0 0}$ seeds. These seeds germinate in both autumn and spring. Seeds are dispersed from July through September (Klinkhamer et al. 1988). Seeds are usually viable in soil for less than a year but have been found on occasion to be viable for $\mathbf{3}$ years. Seed dispersal is extremely limited, and seeds do not require light to germinate (Doucet and Cavers 1996) . Bull thistle is considered a Rank 2 "Significant Threat" by the Tennessee Exotic Pest Plant Council (1996) .

Bull thistle occurs mainly in temperate regions. It can be found in such disturbed areas as roadsides, fields, and quarries. It can also be found along the banks of streams and rivers (Doucet and Cavers 1990.

Bull thistle was introduced to North America, New Zealand, Australia, and Chile from Europe, Africa, and western Asia (Doucet and Cavers 1990) .

Bull thistle can be found in several places on the Oak Ridge Reservation, including fields and sunny places along roads. Control methods are unknown.

\section{REFERENCES:}

Doucet, C., and P. B. Cavers. 1996. A persistent seed bank of the bull thistle Cirsium vulgare. Can. J. Bot. 74:1386-1391.

Klinkhamer, P. G. L., T. J. De Jong, and E. Van Der Meijden. 1988.Production, dispersal and predation of seeds in the Biennial Cirsium vulgare. J. Ecol. 76:403-414.

Tennessee Exotic Pest Plant Council. 1996. Available on-line [http://www.seeppc.org/doc.cfm?id=473]. Cited Mar. 9,2001.

Nomenclature taken from: Wofford, B. E., and R. Kral. 1993. Checklist of the Vascular Plants of Tennessee. 
COMMON NAME:

SCIENTIFICNAME: DESCRIPTION:

HABITAT:

INTRODUCTION:

OCCURRENCE ON ORR:

CONTROL
Chinese yam (Air potato)

Dioscorea batatas Decne.

Chinese yam is a vine with opposite leaves that may sometimes occur in alternate or 3-leaf whorls. Stems climb by curling from left to right, as opposed to the native yam (Dioscoreavillosa), whose stems curl from right to left. Chinese yam produces miniature aerial bulbils within the leaf axils. These bulbils are produced from August through October and then fall to the ground, re-sprouting the following spring. Chinese yam rarely produces flowers in the United States and inflorescences rarely mature (Nabors 1996). It is considered a Rank 2 "Significant Threat" by the Tennessee Exotic Pest Plant Council (1996). Chinese yam can be found growing in alluvial woods, fence rows, roadsides, and other disturbed areas. It primarily occurs in the piedmont and mountain areas of the southeastern United States (Radford et al. 1968). Chinese yam was originally introduced from China to Europe in the mid-1800s as an alternative food crop during the potato blight. It is believed to have been brought to the United States by European settlers. Chinese yam is used in China, Japan, Korea, and Taiwan as a food crop. The yam is useful if allowed to grow for at least 3 years, at which point, the tuber may reach up to a meter in length. The Chinese yam is often used in Europe and the United States as a decorative ground cover and climbing vine (Nabors 1996).

Chinese yam is found throughout the National

Environmental Research Park. It is most prevalent along roads and in disturbed areas.

Chinese yam resprouts from its bulbils. The yam must be pulled from the ground, thus removing its underground tubers as well as its aboveground bulbils. The resulting material must be disposed of properly in order to assure that no resprouting will occur. Larger stems may be cut treated with a glyphosate herbicide.

\section{REFERENCES:}

Nabors, Pamela J. 1996. The current status and potential spread of an invasive exotic species: Chinese yam (Dioscoreu batatas) in the Great Smoky Mountains National Park. M.S. thesis. University of Tennessee, Knoxville, Tenn.

Radford, A. E., H. E. Ahles, and C. R. Bell. 1968. Manual of the Vascular mora of the Carolinas. The University of North Carolina Press, Chapel Hill, N.C.

Tennessee Exotic Pest Plant Council. 1996. Available on-line [http://www.seeppc,org/doc.cfm?id=473]. Cited Mar. 9,2001. 
COMMON NAME:

SCIENTIFICNAME:

DESCRIPTION:

HABITAT:

INTRODUCTION:

OCCURRENCEON ORR:

CONTROL:
Autumn olive

\section{Elaeagnus umbellata}

Autumn olive is a deciduous shrub with alternate leaves that are oval and untoothed. The underside of the leaves are covered with silvery-white scales. Small, yellow leaves occur late in the growing season and round reddish-pink fruits are produced in great quantities. Autumn olive has nitrogen-fixing root nodules, which allow it to thrive in poor soils (Paschke et al. 1989). It is considered a Rank 1 "Severe Threat" by the Tennessee Exotic Pest Plant Council (1996).

Autumn olive tends to prefer disturbed areas including roadsides, forest edges, and pastures. It has, however, been spotted on at least one occasion within an undisturbed forest.

Autumn olive was introduced to the United States from in the 1830s. It was brought from East Asia and can now be found throughout the eastern and central United States. Autumn olive was used to re-vegetate disturbed areas (Virginia Native Plant Society 2000).

Autumn olive can be found growing along most roadsides and power-line cuts. It is especially dense along Bethel Valley Road.

The best method for control of autumn olive is to cut the shrub and treat the stump with a glyphosate herbicide.

The stump must be treated because otherwise resprouting will occur and the problem ma y become worse. Handpulling is effective for removing seedlings if the roots are removed as well (Virginia Native Plant Society 2000).

\section{REFERENCES:}

Paschke, M. W., J. O.Dawson, and M. B. David. 1989. Soil nitrogen mineralization in plantations of Juglans nigra interplanted with actinorhizal Elaeagnus umbellata or Alnus glutinosa. Plant Soil 118:33-42.

Tennessee Exotic Pest Plant Council. 1996. Available on-line [http://www.seeppc.org/doc.cfm?id=473]. Cited Mar. 9, 2001.

Virginia Native Plant Society. 2000. Available on-line

[http://www.dcr.state.va.us/dnh/fselum.pdfI.ited Aug. 28, 2000. 
COMMON NAME:

SCIENTIFICNAME:

DESCRIPTION:

HABITAT:

INTRODUCTION:

OCCURRENCEON ORR:

CONTROL:
Chinese lespedeza (sericea lespedeza)

Lespedeza cuneata (Dum. Cours.) G. Don

Chinese lespedeza is a member of the pea family. It is an herbaceous to woody perennial with compound leaves, each with three leaflets. Leaflets are cuneate and flowers are white with purple veins and can be found at the base of the upper leaves. Chinese lespedeza alters the soil nutrient content by adding nitrogen (Virginia Native Plant Society 2000). Lespedeza seeds can remain viable in the soil for up to 20 years, making scarification necessary for germination (Plant Conservation Alliance 1998). Lespedeza has deep roots that allow it to thrive on dry slopes and abandoned mines. It was used regularly in the past couple of decades to stabilize slopes (Guernsey 1970). Chinese lespedeza is considered a Rank 1 "Severe Threat" by the Tennessee Exotic Pest Plant Council (1996).

Chinese lespedeza appears to prefer open, sunny areas. It can be found along roads, power line cuts, cedar barrens, and waterfronts on the Oak Ridge Reservation (ORR). Chinese lespedeza was introduced to the United States from Asia (Virginia Native Plant Society 2000). It has been introduced for use as a forage crop and is now a significant food source for bob white quail who make it from $1.5 \%$ to $\mathbf{8 6 . 8 \%}$ of their annual diet (Plant Conservation Alliance 1998). It can now be found throughout the southern United States and in parts of the Midwest (Virginia Native Plant Society 2000).

Chinese lespedeza occurs along nearly every road on the ORR. It can also be found in power line rights-of-way, abandoned fields, and lake edges.

According to the Virginia Native Plant Society, the best method for controlling Chinese lespedeza is to mow it during the period of time when it is flowering. It is during this time that root reserves are low. This process should be repeated for 3 to 4 years in order to reduce the intensity of growth (Virginia Native Plant Society 2000). Prescribed burning may be the most effective method for long-term control. Fire will force lespedeza seeds to germinate, and, when followed by mowing, can reduce the number of years in which the procedure must be repeated. Foliar herbicide application is not recommended because of its inability to target a particular species (Virginia Native Plant Society 2000).

\section{REFERENCES:}

Guernsey, Walter J. 1970. Sericea Lespedeza: Its use and management. U.S. Department of Agriculture Farmers' Bulletin No. 2245.

Tennessee Exotic Pest Plant Council. 1996. Available on-line [http://www.seeppc.org/doc.cfm?id=473]. Cited Mar. 9,2001. 
Plant Conservation Alliance, Alien Plant Working Group. 1998. Available on-line [http://www.nps.gov/plants/alien/fact/lecu1.htm]. Cited Aug. 10, 2000.

Virginia Native Plant Society. 2000. Available on-line

[http://www.vnps.org/invasive/invfslesp.htm] Cited Aug. 10, 2000. 
COMMON NAME:

SCIENTIFIC NAME:

DESCRIPTION:

HABITAT:

INTRODUCTION

OCCURRENCE ON ORR:

CONTROL:
Chinese privet (privet)

Ligustrum sinense Lour.

Chinese privet is a semideciduous shrub that can grow up to 10 meters in height. Leaves are opposite and elliptic in shape (Cuda and Zeller 2000). Twigs are pubescent (Gleason and Cronquist 1963). Chinese privet produces small white flowers that bloom from June to July and dark blue fruits that are often eaten by birds and thus spread to surrounding areas (Cuda and Zeller 2000). Each fruit contains 1 to 4 seeds that ripen during September and October. Each individual plant is capable of producing hundreds of fruit (Tennessee Exotic Pest Plant Council 1996a). Chinese privet is considered a Rank 1 "Severe Threat" by the Tennessee Exotic Pest Plant Council(1996b). Chinese privet resides in disturbed areas along roads and in abandoned fields. It also grows readily along stream banks (Cuda and Zeller 2000). It does not prefer high elevations and is not found above 3000 feet. Privet is shade tolerant and can be found living in forests; however, it does not often produce fruit in low-light conditions (Tennessee Exotic Pest Plant Council 1996a).

Chinese privet was introduced from Asia to the United States in 1852. By 1932, it had become naturalized throughout the southeastern United States (Cuda and Zeller 2000).

Chinese privet is found in many areas at ORR. Chinese privet is troublesome because unlike most of the other invasive plant species, it is found within Natural Areas.

Chinese privet will resprout upon cutting, thus it is necessary to use an herbicide glyphosate on stumps in order to kill the roots. According to Cuda and Zeller, a biological control of Chinese privet may already be occurring. The seed weevil Ochyromera ligustri has been observed feeding on privet stands in Florida. The weevil feeds on the leaves, thus weakening them. It lays its eggs inside the fruit, which subsequently destroys the seeds when the larvae hatch and begin to feed on them (Cuda and Zeller 2000).

\section{REFERENCES:}

Cuda, J. P., and M. C. Zeller. 2000. Chinese privet, Ligustrum sinense: prospects for classical biological control in the southeastern United States. Wildland Weeds 17-19.

Gleason, Henry A., and Arthur Cronquist. 1963. Manual of Vascular Plants of Northeastern United States and Adjacent Canada. D. Van Nostrand Company, Inc., New York.

Tennessee Exotic Pest Plant Council. 1996a. Available on-line [http://www.seeppc.org/doc,cfm?id=473], Cited Mar.9,2001.

Tennessee Exotic Pest Plant Council. 1996b. Tennessee Exotic Plant Management Manual. Available on-line [http://www.se-eppc.org/states/manual.pdfited Aug. 23, 2000. 
COMMON NAME:

SCIENTIFICNAME:

DESCRIPTION:

HABITAT:

INTRODUCTION:

OCCURRENCE ON ORR:

CONTROL:
Japanese Honeysuckle

Lonicerajaponica Thunb.

Japanese honeysuckle is a climbing vine with hairy stems on its younger branches and hollow stems when the branches get older. Leaves are normally oblong but can be toothed or lobed. Japanese honeysuckle can grow up to $\mathbf{3 0}$ feet long. It flowers throughout summer and flowers are white with a pinkish interior when young and a yellow interior when older. Honeysuckle produces black bemes that contain many seeds in autumn. The vine produces stolons that can root when they come into contact with soil (Virginia Native Plant Society 2000). Japanese honeysuckle is considered a Rank 1 "Severe Threat" by the Tennessee Exotic Pest Plant Council (1996). Japanese honeysuckle prefers disturbed areas, such as fields, fence rows, and roadsides (Virginia Native Plant Society 2000). The vine, however, can often be found throughout undisturbed areas.

Japanese honeysuckle was introduced to the United States from Asia in 1862. It is now well established throughout the eastern and central United States (Virginia Native Plant Society 2000).

Japanese honeysuckle has been noted in almost every Research Park Natural Area and Reference Area surveyed in this study. It is usually more dense along forest edges and fence rows but can be seen in small numbers throughout undisturbed areas as well. Hand-pulling is most effective for small populations of honeysuckle. Prescribed burning is effective where large populations occur (Virginia Native Plant Society 2000).

\section{REFERENCES:}

Tennessee Exotic Pest Plant Council. 1996. Available on-line [http://www.seeppc.org/doc.cfm?id=473]. Cited Mar. 9, 2001.

Virginia Native Plant Society. 2000. Available on-line

[http://www.vmps.org/invasive/invloni.htm] Cited Aug. 23, 2000. 
COMMONNAME:

SCIENTIFICNAME: DESCRIPTION:

HABITAT:

INTRODUCTION:

OCCURRENCE ON ORR:

CONTROL:
Spearmint

Mentha spicata L.

Spearmint has terminal spike-like inflorescences with white flowers. Female plants can occur alongside hermaphroditic plants and can be distinguished by the absence of the anther. Spearmint is well adapted to drought conditions. It flowers from July through September. Mentha spicatu is thought to be a hybrid of Mentha suaveolens and Mentha longifolia (Kokkini and Vokou 1989). There is evidence that spearmint may reproduce vegetatively (Hirata et al. 1990). Spearmint is considered a Rank 3 "Lesser Threat" by the Tennessee Exotic Pest Plant Council which means that it "seems to principally spread and remain in disturbed comdors, not readily invading natural areas" (TennesseeExotic Pest Plant Council 1990) . Spearmint grows in wet areas.

Spearmint is native only to the Balkan Peninsula Northwestern Turkey. It has been introduced and naturalized in the United States, Europe, and throughout the Mediterranean (Kokkini and Vokou 1989). It has been widely used as a culinary herb (Hirata et al. 1990) . $\boldsymbol{A n}$ extensive patch of spearmint has been found in Hembree Marsh.

Control methods are unknown.

\section{REFERENCES:}

Hirata, T., S. Mura Kami, K. Ogihara, and T. Suga. 1990. Volatile monoterpenoid constituents of the plantlets of Mentha spicatu produced by shoot tip culture. Phytochemistry 29:493-495.

Kokkini, S., and D. Vokou. 1989.Mentha spicatu (Lamiaceae) chemotypes growing wild in Greece. Econ. Bot. 43:192-202.

Tennessee Exotic Pest Plant Council. 1996. Available on-line [http://www.seeppc.org/doc.cfm?id=473]. Cited Mar. 9,2001. 
COMMON NAME:

SCIENTIFICNAME: DESCRIPTION:

HABITAT:

INTRODUCTION:

OCCURRENCE ON ORR:

CONTROL:
Microstegium (Japanese grass, Nepal grass, wiregrass)

Microstegiurn virnineurn (Trin.) A. Camus

Microstegium is a $\mathrm{C}_{4}$ annual grass with stems that may grow up to $\mathbf{4 0}$ inches long and are capable of rooting at the stem nodes (Barden 1987). Its leaves are tapered at both ends and are generally 4 to 5 inches in length and a half-inch wide. Each plant may produce between 100 and 1000 seeds that may remain viable in the soil for 3 to 5 years (Virginia Native Plant Society 2000). Inflorescences are terminal with spike-like racemes, and stalks are pubescent (Godfrey and Wooten 1979). Microstegium is considered a Rank $\mathbf{1}$ "Severe Threat" by the Tennessee Exotic Pest Plant Council (1996).

Microstegium is shade tolerant and can grow in variable light conditions because of its low-light compensation points and lowdark respiration rates. These allow the plant to continue to assimilate $\mathrm{CO}_{2}$ in the darkness of the understory (Horton and Neufeld 1998). In fact, microstegium has been observed growing in areas that receive only 5\% full sunlight (Barden 1987). Although microstegium is often found in shady environments, it has been noted to grow in full sunlight. Microstegium appears to prefer moist soils and can often be found in low woods, floodplains, streambanks, roadsides, and woodland borders (Virgina Native Plant Society 2000).

Microstegium was first introduced to the United States in 1919 in Knoxville, Tennessee. It is native to Korea, Malaysia, India, and Japan (Virginia Native Plant Society 2000). It can now be found throughout the Southeastern United States (Horton and Neufeld 1998).

Microstegiumis found throughout the ORR. It appears to be the most problematic invasive plant found on the ORR. Although it is most often associated with disturbed areas, it is not restricted to these areas. In many instances, it was observed growing in undisturbed areas.

The best method of control of microstegium is hand removal just before seed production of the next growing season. According to the Virginia Native Plant Society, this procedure must be repeated for at least seven years because of the longevity of seed viability in the soil (Virginia Native Plant Society 2000). Burning and mowing are not effective because they do nothing to remove the seed bank. A glyphosate herbicide will work effectively against microstegium; however, it works effectively against all green vegetation and is not recommended because of the possibility of losing native species (Virginia Native Plant Society 2000). 


\section{REFERENCES:}

Barden, Lawrence S. 1987. Invasion of Microstegiurn virnineurn (Poaceae), an exotic, annual, shade-tolerant, $\mathrm{C}_{4}$ grass, into a North Carolinafloodplain. Oecologia 118:40-45.

Godfrey, R. K., and J. W. Wooten. 1979. Aquatic and Wetland Plants of Southeastern United States. The University of Georgia Press, Athens, Ga.

Horton, J. L., and H. S. Neufeld. 1998. Photosynthetic responses of Microstegiurn vimineurn (Trin.) A. Camus, a shade-tolerant, $\mathrm{C}_{4}$ grass, to variable light environments. $\boldsymbol{A} \boldsymbol{m}$. Midland Nat. 114:11-19.

Tennessee Exotic Pest Plant Council. 1996. Available on-line [http://www.seeppc.org/states/doc.cfm?id=469].Cited May 17,2002.

Virginia Native Plant Society. 2000. Available on-line

[http://www.dcr.state.va.us/dnh/fsmivi.pdfl.Cited Aug. 26, 2000. 
COMMON NAME:

SCIENTIFICNAME:

DESCRIPTION:

HABITAT:

INTRODUCTION:

OCCURRENCE ON ORR:

CONTROL:
Watercress

Nasturtium officinale R.Br.

Watercress is a perennial, succulent plant that obtains nitrogen directly from the water in which it grows (Shear 1970). It is a

- macrophyte that lives in north temperate regions. It is an amphibious crucifer, meaning that it is a member of the Cruciferae family (Kerfoot et al. 1998). Watercress is also a helophyte with perennating buds below the surface of the marsh (Bornetteet al. 1994) . It is considered a Rank 2 "Significant Threat" by the Tennessee Exotic Pest Plant Council (1990) . Watercress lives mostly in streams, ditches, and other areas where moving water may be present. It prefers a cooler climate but grows very well in the hilly southern states (Shear 1970).

Watercress was introduced to the United States from Europe in the 1700s (Kerfoot et al. 1998).

Watercress was found in two different Natural Areas on the ORR. It was observed growing within a stream in Natural Area 43 and beside a stream in Natural Area 47.

Options for biological control of watercress include the watercress sowbug, which chews through the underwater stems of the plant and causes the plants to drift

downstream. Muskrats also feed on watercress and burrow in the soil which disturbs rooting (Shear 1970).

\section{REFERENCES:}

Bornett, G., C. Amoros, C. Castella, and J. L. Beffy. 1994. Succession and fluctuation in the aquatic vegetation of two former Rhône River channels. Vegetatio 110:171-184.

Kerfoot, W. C., R. M. Newman, and Z. Hanscom III. 1998. Snail reaction to watercress leaf tissues: reinterpretation of a mutualistic 'alarm' hypothesis. Freshwater Biol. 40:201-213.

Shear, G. M. 1970.Commercial growing of watercress. U.S. Department of Agriculture, Farmers' Bulletin No. 2233. Washington, D.C.

Tennessee Exotic Pest Plant Council. 1996. Available on-line [http://www.seeppc.org/doc.cfm?id=473]. Cited Mar. 9,2001.

Nomenclature taken from: Wofford, B. E., and R. Kral. 1993. Checklist of the Vascular Plants of Tennessee. 
COMMON NAME:

SCIENTIFICNAME: DESCRIPTION:

HABITAT:

INTRODUCTION:

OCCURRENCEON ORR:

CONTROL:
Empress tree (Princess tree)

Paulownia tornentosa (Thunb.) Steud.

The empress tree is a rapidly growing tree that can easily invade disturbed areas, especially areas that have a higher soil $\mathrm{pH}$, like abandoned strip mines (Turner et al. 1988). The empress tree produces prolific amounts of winged seeds that are shade intolerant, requiring sunlight to germinate. A single tree can produce up to $2 * 10^{7}$ seeds (GrubiSic and Konjevic 1992). Each seed capsule usually contains 2,000 seeds that are left behind after the fall leaves are shed and often rattle in wind, giving the empress tree its nickname rattlebox. The flowers are tubular and a pale violet color. Leaves are opposite and heart-shaped (Sand 1992). The empress tree reproduces not only by seed but by root suckering as well. In fact, root sprouts may grow up to $\mathbf{1 5}$ feet per season (Plant Conservation Alliance 1998). The empress tree is considered a Rank 1 "Severe Threat" by the Tennessee Exotic Pest Plant Council (1996).

The empress tree prefers a mild, temperate climate (Hui-jun and Ingestad 1984). It grows well on poor soils, making it common in disturbed areas (GrubiSic and Konjevic 1992). The empress tree can be found in such disturbed areas as roadsides and abandoned strip mines. It can also be found growing along stream banks and forest edges (Plant Conservation Alliance 1998).

The empress tree was introduced to Europe from China and was introduced to the United States in 1845. It can now be found from New York to Florida and as far west as Texas (Sand 1992). The purpose for introduction was for use as a park tree (GrubiSic and Konjevic 1992).

The empress tre can be found in several areas on the Oak Ridge Reservation but mostly in disturbed areas, such as roadsides. Hand pulling is the best method of control for young plants as long as all of the roots are removed to prevent resprouting. Cutting at ground level is effective for removing larger trees. Stumps must be treated with a glyphosate herbicide to prevent resprouting.

\section{REFERENCES:}

GrubiSic, D., and R. Konjevic. 1992. Light and temperature action in germination of seeds of the empress tree (Paulowniatornentosa). Physiol. Plant. 86:479-483.

Hui-jun, J., and T. Ingestad. 1984. Nutrient requirements and stress response of Populus Simonii and Paulownia tornentosa. Physiol. Plant. 62 117-124.

Plant Conservation Alliance, Alien Plant Working Group. 1998. Available on-line [http://www.mps.gov/plantdalien/fact/patol.htm]Cited Aug. 29, 2000. 
Sand, Susan. 1992. The Empress Tree: Paulownia tomentosa has been both vilified and venerated. Am. Hort. 71:27-29.

Tennessee Exotic Pest Plant Council. 1996. Available on-line [http://www.seeppc.org/doc.cfm?id=473]. Cited Mar. 9,2001.

Turner, G. D., R. R. Lau, and D. R. Young. 1988. Effect of acidity on germination and seedling growth of Paulownia tomentosa. J. Appl. Ecol. 25:561-567.

Nomenclature taken from: Wofford, B. E., and R. Kral. 1993. Checklist of the Vascular Plants of Tennessee. 
COMMON NAME:

SCIENTIFIC NAME:

DESCRIPTION:

HABITAT:

INTRODUCTION:

OCCURRENCEON ORR:

CONTROL:
Kudzu

Pueruriu montana (Willd.) Ohwi

Kudzu is a leguminous perennial vine that spreads locally through vegetative reproduction. It is rarely spread by seed because of poor seedling establishment. Kudzu is highclimbing and can completely blanket existing vegetation (Sasek and Strain 1989) .

Kudzu grows in disturbed areas such as roadsides and abandoned fields. It can often be seen encroaching onto adjacent forest margins.

Kudzu was introduced to the Eastern United States in 1876 (Sasek and Strain 1989).

Kudzu occurs in few places on the ORR. It can be found growing in power line cuts and other disturbed areas.

Kudzu is very difficult to control but can be managed through manual removal and stump treatment with a glyphosate herbicide (Tennessee Exotic Pest Plant Council 1990).

\section{REFERENCES:}

Sasek, T. W., and B. R. Strain. 1989. Effects of carbon dioxide enrichment on the expansion and size of Kudzu (Pueraria lobata) leaves. Weed Sci. 37:23-28.

TennesseeExotic Pest Plant Council. 1996. Available on-line [http://www.seeppc.org/doc.cfm?id=473]. Cited Mer. 9, 2001.

Nomenclature taken from: Wofford, B.E., and R. Kral. 1993. Checklist of the Vascular Plants of Tennessee. 
COMMON NAME:

SCIENTIFIC NAME: DESCRIPTION:

HABITAT:

INTRODUCTION:

OCCURRENCEON ORR:

CONTROL:
Multiflora rose

Rosa multiflora Thunb. ex Murray

Multiflora rose is a perennial shrub with stems that are trailing and can root at the tip. The leaves are compound, alternate, and toothed (Virginia Native Plant Society 2000). Flowers are white and bloom in May or June (Szafoni 1991). Multiflora rose seeds are photoblastic and sensitive to light (Yambe et al. 1995). Fruits are red hips that are eaten by birds and thus, spread rapidly. Multiflora rose produces dense thickets that are highly competitive for soil nutrients and can shade out native plants (Virginia Native Plant Society 2000). It reproduces both vegetatively through layering and by seed. Seeds are viable in soil for 10 to 20 years (National Park Service 2000). Multiflora rose is considered a Rank 1 "Severe Threat" by the Tennessee Exotic Pest Plant Council (1996).

Multiflora rose can be found growing not only in such disturbed areas as agricultural lands and pastures, but also in natural areas, such as savannas, prairies, and open woodlands (Szafoni 1991). Multiflora rose is native to Japan and other areas in northeastern Asia. It was introduced to the United States on several occasions within the last 200 years (Epstein et al. 1997).

Multiflora rose can be found growing along roads and forest edges on the ORR. Large populations can be found growing along the edge of the Bull Bluff Natural Area. Multiflora rose can be controlled by pulling plants from the soil. It is important to remove all roots from the soil, as they will resprout. Cutting the plant at ground level is also effective if a glyphosate herbicide is applied to the stump. Routine prescribed burning can also be effective in preventing the growth of multiflora rose. No known effective biological controls exist at this time. Rose rosette disease is a viral disease that can destroy multiflora rose, but is not recommended as a control because it may also affect native and ornamental roses (Szafoni 1991).

\section{REFERENCES:}

Epstein, A. H., J. H. Hill, and F. W. Nutter, Jr. 1997. Augmentation of Rose Rosette Disease for biocontrol of multiflora rose (Rosa multiflora). Weed Sci. 45: 172-178.

National Park Service. Available on-line [http://www,nps.gov/ncro/rocr/exotics/species/Rosa_multiflora.html]. Cited Sept. 30, 2000.

Szafoni, R. E. 1991. Vegetation management guideline: Multiflorarose. Nat. Areas J. 11:215216.

Tennessee Exotic Pest Plant Council. 1996. Available on-line [http://www.seeppc.org/doc.cfm?id=473]. Cited Mar. 9,2001. 
Virginia Native Plant Society.2000. Available on-line

[http://www.vnps.org/invasive/invfslesp.htm.Gited Sept. 30, 2000.

Yambe, Y., K. Takeno, and T. Saito. 1995. Light and phytochrome involvement in Rosa

multiflora seed germination.J. Am. Soc. Hort. Sci. 120953-955.

Nomenclature taken from: Wofford, B. E., and R. Kral. 1993. Checklist of the Vascular Plants of Tennessee. 
COMMON NAME:

SCIENTIFICNAME:

DESCRIPTION:

HABITAT:

INTRODUCTION:

OCCURRENCE ON ORR:

CONTROL:
Johnsongrass

Sorghum halepense (L.) Pers.

Johnsongrass grows by seed, branched rhizomes, and fleshy rhizomes (Smeda et al. 1997). It is considered a Rank 1 "Severe Threat" by the Tennessee Exotic Pest Plant Council (1996) .

Johnsongrass is a problem in the croplands of $\mathbf{5 8}$ countries (Smeda et al. 1997) .

Johnsongrass is considered to be the fifth most problematic pest plant in the southeastern United States (Barrentine and McWhorter 1988) .

Johnsongrass is found along almost every road edge on the Oak Ridge Reservation.

One study found that Johnsongrass rhizomes could be controlled by spraying sethoxydim, quizalofop, and haloxyfop in paraffin oil on the plant (Barrentine and McWhorter 1988).

\section{REFERENCES:}

Barrentine, W. L., and C. G. McWhorter. 1988.Johnson grass (Sorghum halepense) control with herbicide in oil dilutents. Weed Sci. 36:102-110.

Smeda, R. J., C. E. Snipes, and W. L. Barrentine. 1997. Identification of graminicide-resistant Johnson grass (Sorghum halepense). Weed Sci. 45:132-137.

Tennessee Exotic Pest Plant Council. 1996.Available on-line [http://www.seeppc.org/doc.cfm?id=473]. Cited Mar. 9, 2001.

Nomenclature taken from: Wofford, B. E., and R. Kral. 1993. Checklist of the Vascular Plants of Tennessee. 
COMMON NAME:

SCIENTIFIC NAME:

DESCRIPTION:

HABITAT:

INTRODUCTION:

OCCURRENCE ON ORR:

CONTROL:
Greater periwinkle

Vinca minor L.

Periwinkle is an herbaceous evergreen that is very coldtolerant. It is an angiosperm with leaves that develop in spring and summer (Huner et al. 1988). Periwinkle produces blue flowers in the spring and disperses its seeds throughout the summer; however, vegetative reproduction seems to dominate (Schulz and Thelen 2000). It is considered a Rank 2 "Significant Threat" by the Tennessee Exotic Pest Plant Council (1996).

Periwinkle is a shade-tolerant plant and is a good competitor in shade (Hottes 1947).

Periwinkle was introduced to the United States from Asia and southern Europe. It can now be found throughout the eastern and central United States (Schulz and Thelen 2000). Periwinkle can often be found in areas where a cemetery or old homesite can be found. It is prevalent in Walker Branch and can be found growing together with microstegium.

Foliar application of 2,3,6-trichlorobenzoic acid is effective if used to the point of being washed into the soil. A glyphosate herbicide will not work because it is unable to penetrate periwinkle's thick outer cuticle (The Nature Conservancy 2000). Periwinkle has been found to be susceptible to foliar diseases caused by Phoma exigua and Colletotrichum gloeosporioides (Koelsch et al. 1995).

\section{REFERENCES:}

Hottes, A. C. 1947. Climbers and Ground Covers. A.T. De La Mare, New York.

Huner, N. P. A., M. Krol, J. P. Williams, and E. Maissan. 1988. Overwintering periwinkle (Vinca minor L.) exhibits increased photosystem I activity. Plant Physiol. 87:721-726.

Koelsch, M. C., J. C. Cole, and S. L. von Broembsen. 1995. Effectiveness of selected fungicides in controlling foliar diseases of common periwinkle (Vinca minor L.). HortScience 30:554-557.

The Nature Conservancy. Element Stewardship Abstracts. 2000. Available on-line [http://tncweeds. ucdavis.edu/esadocs/documnts/vincmajhtml]. Cited Mar. 5,2001.

Schulz, K. and C. Thelen. 2000. Impact and control of Vinca minor L. in an Illinois forest preserve (USA). Nat. Areas J. 20189-196.

Tennessee Exotic Pest Plant Council. 1996. Available on-line [http://www.seeppc,org/doc,cfm?id=473]. Cited Mar. 9,2001. 


\section{INTERNAL DISTRIBUTION}

1. D. M. Bradburn

2. G. S. Byrd

3. J. T. Etheridge

4. W. F. Harris

5. J. E. Hensley, Jr.

6. S. G. Hildebrand

7. M. A. Huston

8. J. M. Loar

9-84. P. D. Parr
85. M. G. Ryon

86. M. S. Salk

87. S. M. Trotter

88. R. S. Turner

89. J. W. Webb

90-92. ESD Library

93. ORNL Research Library

94. ORNL Laboratory Records-RC

\section{EXTERNAL DISTRIBUTION}

95. W. Mark Belvin, U.S. Department of Energy, P.O. Box 2008, MS SE31, Oak Ridge, TN 37831-SE31

96-105. Sara J. Drake, Plant Biology and Botany Department, University of Georgia, Athens, Georgia 30602

106. Marianne M. Heiskell, U.S. Departmemt of Energy, Oak Ridge Operations, P.O.

Box 2001, Federal Building, Oak Ridge, TN 37831

107. Clarence. R. Hickey, U.S. Department of Energy, Headquarters, 19901 Germantown Road, SC-83, Germantown, MD 20874-1290

108-117. Jake F. Weltzin, Department of Ecology and Evolutionary Biology, The University of Tennessee, 569 Dabney Hall, Knoxville, TN 37996 
ฯ 